\title{
A Comparative Survey Data Analysis of Declining Oil Revenue Implications on the Economic Performance of Oil-Exporting Countries: Nigeria, Venezuela and Norway
}

\author{
Millicent Adanne Eze ${ }^{1}$ \\ School of Business, Law and Social Sciences, Abertay University, Scotland, United Kingdom
}

\begin{abstract}
The global oil markets have witnessed different episodes of oil price fluctuations at different intervals. The effect of the fluctuations differs across nations and partly depending on the direction of the shocks. Declining oil revenue also has both direct and indirect impact on the economic performance of the countries where the heavy dependency on crude oil prevails. This study is a comparative survey analysis of declining oil revenue implications on the economic performance of oil-exporting countries; the case of highly oil-dependent nations: Nigeria (West Africa), Venezuela (South America) and Norway (Europe). Purposive sampling was used in selecting our samples, while the Survey Monkey cloud-based tool was employed to administer and collect the questionnaires from the targeted audience. Survey data analysis was carried out using SPSS Version 25 and the Survey Monkey platform. The results reveal that both increasing and decreasing oil price affect the oil revenues and the external reserves of Nigeria, Venezuela and Norway proportionately. The outcome also shows that during periods of declining oil revenues, Nigeria and Venezuela attain their budgetary needs through borrowing and seigniorage. On the other hand, Norway utilises its savings with the Sovereign Wealth Fund (SWF) and Pension Funds in financing its fiscal needs, thereby exonerating Norway from the resource curse syndrome. It is recommended that these nations explore other sources of revenue through diversification and the development of other natural resources. Nigeria and Venezuela should also restore security which would help in attracting further foreign investors. They should also ensure effective management of government funds and pay attention to its human capital development. However, an economic model is proposed to aid in closing the revenue gaps in these highly oil-dependent nations, given that the "power of oil" is gradually fizzling out as other alternative forms of energy that are assumed to be environmentally friendly are widely embraced.
\end{abstract}

Keywords:Oil Revenue, Dwindling Oil Price, Comparative Analysis, Survey Data, Economic Model, OilExporters

DOI: $10.7176 / \mathrm{JRDM} / 76-03$

Publication date:June $30^{\text {th }} 2021$

\subsection{Introduction}

Crude oil is an essential source of energy that propels global economic activities and also one of the most dynamically transacted commodities all over the world. Over the years, the trend in the oil price fluctuations and the instability in the global oil market over the years have been as a result of many factors; demand oriented, increasing or decreasing oil supply, speculations, covid-19 pandemic, war, global financial crisis, quest for paradigm shift from a hydrocarbon economy to the ones based on a more sustainable form of energy (Eze and Kouhy 2021; Peng et al., 2020). These uncertainties associated with the constant oil price fluctuation has diversely affected economic activities especially those of the oil exporting countries whose main source of revenues are derived from oil (Van Eyden et al., 2019). Oil is the number one export product in the world as it accounts for about 4.8 per cent of the global total exports while the total value of oil shipments was about $\$ 786.3$ billion in 2015 (Workman, 2016). The price of all the energy-demanding goods and services, as well as the price of other fuels, are to a reasonable extent, linked to the oil price. Hence, an unexpected change in the price of oil tends to have great impact on oil-exporting economies, oil-importing economies and the world in general. Oil price fluctuations are crucial to the global economy since oil serves as the main energy source and raw materials for several industries across the globe (Kitous et al., 2016).

Basically, every nation has a statutory role in developing its economy. Nigeria, Venezuela and Norway, being the focus of this research; like any other nation have been performing this function judiciously in their own peculiar ways through reliance on oil revenue; as such, oil revenues play a very significant role in the structure of most of the oil-exporting countries (Eltejaei, 2015; Aliyan, 2013; Farzanegan, 2011; Farzanegan and Markwardt 2009). The three economies were examined and compared while necessary lessons drawn from the

\footnotetext{
$1 *$ Thanks to all the participants at the Annual Conference of the 2019 Scottish Economic Society (SES), for their useful comments and suggestions. Many thanks also to all the participants at the Abertay Graduate School Conference in 2019, for the insightful comments. I am also very thankful to my sponsor: Tertiary Education Trust Fund (TETFUND) for the funding support of my research degree (PhD) and for this research project. Kindly address all the correspondence to: Dr Millicent Adanne Eze, School of Business, Law and Social Sciences, Abertay University, Dundee, Scotland-United Kingdom; Mobile: +447341325484; E-mail: ezemillicent@gmail.com
} 
Norwegian economy as it is serving as a reference to best practice relative to other oil exporters that are ravaged by the resource curse syndrome.

Most of these oil-exporters are overwhelmingly depending on oil revenue for over half of their exports. Nigeria is blessed abundantly with natural resources as it depends so much on the oil sector, which accounts for over $91 \%$ of its revenue and $82 \%$ of the foreign exchange earnings (Oyelami, 2018). Irrespective of the high proceeds the Nigerian economy have reaped from oil for over three decades now; the nation is still facing so many economic and political crisis; like high level of unemployment, high level of insecurity, low level of production, poor infrastructural development and high level of poverty as over $70 \%$ of the populace are living below the poverty line. The Nigerian economy is also facing severe macroeconomic instability due to its overdependence on oil export, exchange rate depreciation and fiscal imbalances. Nigeria has been forced to raise the interest rates and devalue the naira on several occasions (Adamu 2015; Osuji 2015; Koranyi, 2014; Kabir, 2014; Oriakhi and Iyoha, 2013 Akinlo, 2012).

Nevertheless, Venezuela is one of the hardest hits among its peers as the economy is overwhelmingly dependent on oil than ever. The declining oil revenue has brought about an increase in foreign debt, increase in poverty level, increasing political tension due to economic instability. The economy is falling apart because Venezuela's residents lack access to basic food and the country has also dismissed thousands of its oil workers. They have also scrapped so many projects due to lack of funds (Tong, 2016; Workman, 2016; OPEC Annual Statistical Bulletin, 2016; Monaldi, 2015; Schipani, 2015).

Although the Norwegian economy is also highly dependent on oil revenue, the study reveals that the nation has the largest Sovereign Wealth Fund globally and has mapped out \$41 billion from the oil savings to boost its economy and as a small open economy, Norway is transformed tremendously through the discovery of oil. The Norwegian oil sector constitute about $61 \%$ of the gross domestic product and $57 \%$ of its exports since 2014 . The present slump in crude oil prices has affected Norway's profitability to the extent that three off-shore rigs are under suspension, more than ten thousand Norwegian oil workers have been suspended while over \$150 million worth investments have been put on hold (Paraskova, 2020; Olsen, 2018; Hass et al., 2017; Krakenes, 2015).

The impact of these established factors on oil exporting economies differs across nations as some countries have the capability of "weathering the storm" than others due to their excess savings with the Sovereign Wealth Fund while other nations are having the challenges of high level of public debt, high level of insecurity and unable to attract foreign investments, hence, low level of economic development (Olsen, 2018; Hass et al., 2017; Monaldi, 2015; Schipani, 2015; Pettinger, 2015; Adamu, 2015; Krakenes, 2015).

Recently, the oil industry has witnessed a persistent decline in the oil price and this has correspondingly led to the decline in oil revenues of most of these oil-exporting countries. The concern, therefore, is the ability of these nations to continue with the economic development aspirations in the recent paradigm shift to oil revenue, necessitated by the decreasing oil price. Evaluation of the effects of the declining oil revenues on the budgetary performance of the oil exporters through survey analysis is also one of the concerns of this study given that most studies in the literature had diverse views while most of the related studies were analysed using secondary data only. Some of these studies are: Taghizadeh-Hesari and Yoshino (2015); Kaplan (2015); Yoshino and Taghizadeh-Hesari (2014); Dizaji, (2014); Nwosu and Okafor, (2014); Hesary et al. (2013); Shi and Sun (2012); Farzanegan, (2011).

However, most oil-exporting countries have widening budget deficit gaps due to the decline in oil revenues. Oil revenues constitute a major part of income while the significant drop in government revenue was due to the decrease in oil price and the recessionary trend in these economies highly dependent on oil income. More so, the foreign reserves of these countries are alarmingly very low and are reducing incessantly due to the constant decrease in oil price, as such, those oil-exporting countries whose budgets are relying more on oil revenue are likely to feel the impact more (Luković and Grbić 2014). Indeed, there exists a wide gap between oil prices at which different oil producers break even (Hayes (2015). Oil-exporting economies need the oil price to be at a certain level to balance their national budgets and meet with other fiscal needs. As at the 25th of May 2021, the

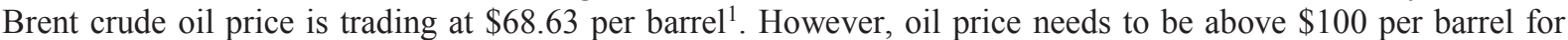
most of these economies to balance their national budgets (Shyam, 2018; Hayes, 2015; Fahey 2015; Rascouet 2015).

Nevertheless, the intricate issue with special concern is the implications of the declining oil revenues of these oil exporting countries especially on Nigeria, Venezuela and Norway's budgetary provisions. Most of these economies are under stress due to the fiscal imbalance, exchange rate depreciation and deteriorating growth prospects imposed by the depressed crude oil price in the world oil market. The purpose of this study therefore, entails the examination of the effect of declining oil revenue on the economic performance of Nigeria, Venezuela and Norway for a comparative analysis using the survey data approach. The power of OPEC, which

\footnotetext{
${ }^{1}$ See OIL-PRICE.NET: Oil Price and Commodity Prices. $25^{\text {th }}$ May 2021.
} 
is also known as "Call-on-OPEC" $"$ has always been to increase oil prices. Thus, in this new price shock, the collusive strength of this oligopoly has failed because OPEC could not control its members production quotas in recent time as the members produce excessively giving rise to increasing oil supply which has forcefully pushed the oil price lower than expected. With the fear of the failure of the power of OPEC and with the trend that this fall in oil price might continue, this research, therefore, aims at closing the revenue gaps in these oil-dependent economies through the proposed economic model.

However, oil related studies are not new, given all the literature reviewed but majority of the examined economies are developed and oil importing (Mohaddes and Raissi, 2015; Taghizadeh-Hesary and Yoshino 2015; Hamilton and Herrera, 2004). Other related studies lay more emphasis on the impact of increasing oil price on the examined economies (Kilian, and Lutkepohl, 2016; Nzimande and Msomis, 2016; Taghizadeh-Hesary and Yoshino 2015; Kaplan, 2015; Eltejaei, 2015; Dizaji, 2014; Hamilton, 2005; 1983; Kilian 2009). Some other related studies are mainly historical as the findings and conclusions are based on previous studies (Eze and Kouhy, 2021; Husain et al., 2015; Adamu, 2015; Yanar, 2014, 2009). However, this study is different from previously outlined studies. It deals with the impact of both increasing and decreasing oil price cum oil revenues of oil-exporting countries as they depend so much on revenues from the oil industry.

Methodologically, the use of survey data is one of the most distinctive aspect of this study relative to others as all the reviewed oil related studies employ the use of secondary data for the analyses. For instance, Peng et al., (2020) used the Nonlinear ARDL in analysing the secondary data of the dynamic characteristics of oil price fluctuation from the crude oil price influence mechanism perspective. Similarly, Roespinoedji, et al., (2019); Nkoro and Uko (2016); Magoti and Mtui, (2020) employed the use of ARDL in analysing the secondary data inherent in their studies. Taghizadeh-Hesary and Yoshino (2015); Akpan and Atan, (2015) used the SVAR, while Farzanegan (2011) and Ali et al., (2015) used VAR in carrying out their analyses, with secondary data in the oil related studies. To the best of my knowledge, there is no other oil related study either for oil-importing, oil-exporting, developed or for developing nations and even for emerging economies carried out survey data analysis. More so, an economic model is proposed in this study to enable Nigeria, Venezuela, and other similar nations close their revenue gaps, given that the "the power of oil" is gradually fizzling out as new forms of energy that are assumed to be environmentally friendly emerge.

\subsection{Literature Review}

The important role of oil in the global economy has attracted lots of attention among researchers, economists and polititians. Undoubtedly, oil price fluctuations have a great impact on the total global economy since it serves as a vital input commodity for most oil importers and a very crucial source of revenue generation for most of the oil-exporting countries. There is indeed a positive correlation between oil price and oil revenue as fluctuations in oil price result to revenue fluctuations as well. The level of impact of the fluctuations differs across nations as it depends on different factors in these economies. These perspectives could be in terms of the macroeconomy as a whole, socio-political factors, international market effects and the level of oil reserves. Also, other factors could be a strategy employed by the firm in an economy, the climatic condition of a nation and even depends on the developmental stage of the economy (Trkulja and Le Coq 2015; Yanar 2014; Aliyan, 2013).

Similarly, Husain et al. (2015) advanced that the magnitude of the impact of the decline in oil price is highly dependent on the engineering factor, the tenacity of the drop-in oil price as well as on the policy outcome. They further maintained that the resultant effects of oil price fluctuations on the global economy are positive since the oil-exporting countries expenditure is likely to be less than the increasing expenditure of those of oilimporting economies. The impact of the decline in the recent slump in oil price decline lowers the living cost of the populace. The real incomes of the oil-consuming economies rise as well. The marginal costs of the industries using oil as an input factor reduce; thereby reducing the actual prices for their goods and services while motivating the supply of oil. Also, Eze and Kouhy, (2021) carried out a historical review of the impact of fluctuating oil prices on both oil-exporting and oil-importing through the new-normal era by capturing all the detailed oil price shock events at different intervals from 1946-2020. However, no analysis was carried out as the study centres mainly on the historical perspective of the subject.

Most of the related studies address the issue as to whether there is any correlation between fluctuations in oil price and the macroeconomy. Hamilton carried out the pioneering study on the United State of America and found that oil was one of the most crucial instrument responsible for all the past recessions in the USA (Farzanegan and Markwardt, 2009; Cunado and Garcia, 2005; Hamilton, 1983). On the contrary, Darby (1982) found no relation between oil price and the macroeconomic variables. Similarly, Hooker, (1996) found no relationship between oil price fluctuation and macroeconomic variables. In 1999, Hooker maintained that the relationship between oil price fluctuation and macroeconomic variables might be very difficult to identify due to the behavioural nature of the oil price time series data. Hamilton, (2003) and Mork, (1989) maintain that what

\footnotetext{
1 The power of OPEC known as "Call-on-OPEC" See OECD/IEA 2015 and Patterson, 2014
} 
matters most is the increases in oil price rather than decreasing oil price on an economy. Bohi (1991) also argued that the oil price does not have any substantial macroeconomic effects by themselves. Nzimande and Msomis (2016) on examining oil price changes and economic activity in South Africa suggests that both increasing and decreasing oil price shocks are important as they both have asymmetric impacts on economic activities. Hamilton contends that increasing oil price is much more important in predicting the GDP of an economy rather than oil price decreases. Using an SVAR framework, Taghizadey-Hesary and Yoshino, (2015) examined the impact of oil price fluctuations on the growth rate of GDP and inflation in the United States, China and Japan. The result reveals that the implications of the fluctuations in the oil price of an emerging economy's GDP growth are higher when compared to the GDP of developed oil importers. Also, Farzanegan and Markwardt, (2009) used a VAR framework for the Iranian economy and analysed the dynamic relationship between oil price fluctuations and macroeconomic variables. The result indicates that both positive and negative oil price shock increases inflation while a positive correlation exists between increasing oil price and output growth.

On the other hand, Aliyan (2013) posits that, fluctuations in oil price and the macroeconomic variables are highly unpredictable since the oil exporters and oil importers are affected differently. Shi and Sun, (2012) examined the relationship between oil price and the macroeconomy in China and India. They concluded that there is no substantial causality between oil price fluctuation and most macroeconomic variables. Nevertheless, Lee et al., (1995) and several other researchers argue that the high inconsistency inherent in the results of oil price fluctuations after 1985 periods portray elements of misspecification. Hooker, (1996) also maintain that the correlation between oil price shock and economic activities appear much weaker in all the data obtained since 1985. This gave rise to the need of running oil price changes through the application of the nonlinear models in order to capture the macroeconomic effects.

Contrary to the above, Al-Quadsi and Ali, (2016) portrayed that the fluctuations in oil price have both the long and short-term effects on the macroeconomy. For the United Kingdom, Lorusso and Peironi, (2015) examined the causes and consequences of oil price fluctuations and found that the real oil price and domestic inflation have positive correlation while growth in the gross domestic product falls with the decline in the supply of oil. Ogundipe et al. (2014) assert that oil price changes have a significant effect on the exchange rate volatility in Nigeria. In addition, Oriakhi and Iyoha (2013) reviewed the effect of an oil price shock on Nigeria's economic growth and concluded that there exists a relationship between oil price changes and macroeconomic variables. As such, the Nigerian economy is very susceptible to oil price fluctuations, which has made it difficult for the attainment of the expected growth target. On the contrary, Arewa and Nwakahma, (2013) examination of this relationship in Nigeria as well reveals that the variables do not Granger ${ }^{1}$ cause each other. More so, Iwayemi and Fowowe (2011) reveal that oil price fluctuation has no significant impact on the main macroeconomic variables. Relatively, Olomola and Adejumo, (2006) work in Nigeria suggests a substantial impact of oil price fluctuations on macroeconomic variables, thereby confirming the Dutch disease syndrome in Nigeria. Also, Eltony and Al-Awadi (2001) examined this impact in Kuwait and found that there is a high degree of the interrelationship among major macroeconomic variables. However, all the data analysed are secondary data. Monaldi (2015) carried out a historical analysis of the impact of decreasing oil prices on the Venezuela's macroeconomy. The results indicate that there is an existence of inflation rate (3-digit), deficit in the current account, a decrease in the gross domestic product, production contraction, economic instability and a very high political instability. Turkey as an oil-importing nation is examined by Aydin and Acar (2011); the results indicate that there are significant effects of increasing oil prices on macro indicators and about 5 percent rise in inflation. They also reveal that the increasing oil price makes it very hard for economies with large oil import financial plan to be able to settle their budget shortfalls. Hesary et al. (2013) estimated the impact of oil price shocks on oil-exporting economies (Iran, Russia, and Canada) and their trade partners. The results show that the direct and indirect effects of an increasing oil price on the gross domestic products of Iran and Russia are significant while the direct effect is insignificant for Canada due to the small impact that the oil export contributes to their gross domestic product. The indirect effect on Canada is significant due to their high involvement in exporting the end-products.

Nevertheless, most of these oil-exporting countries already outlined the oil prices needed to balance the national budget which is obviously higher than the prevailing oil price. The Oil price as at the $27^{\text {th }}$ of May 2021, was sold at $\$ 68.63$ per barrel for Brent Crude and $\$ 68.63$ per barrel for WTI crude oil (OilPrice.com (2021). According to Deutsche Bank Research (2014), breakeven oil prices needed to balance budget are as shown in figure 2.1 below.

\footnotetext{
${ }^{1}$ The lagged values of the time series variables granger cause each other when the values of one of the variables provide statistical information about the future value of the other variable.
} 
Figure 2. 1 Oil Price Needed to Balance the National Budgets

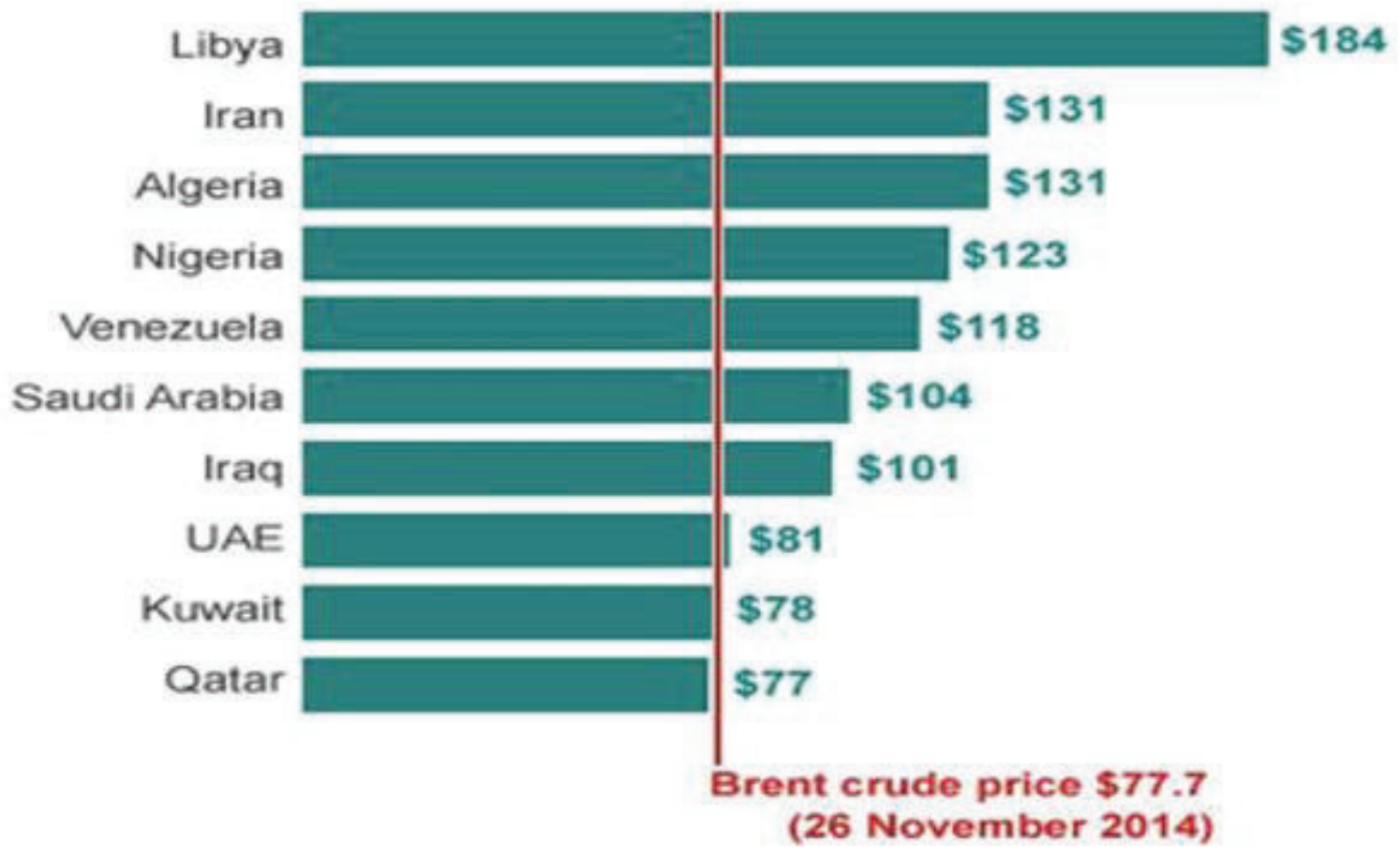

Deutsche Bank Research (2014)

Consistently, Hayes (2015) examined falling oil prices and the break-even oil prices needed by most of the oil producers to balance budgets. The study reveals that Libya needs oil price to rise to $\$ 184$ per barrel, Iran$\$ 313$ per barrel, Iraq - \$101.50 per barrel, Venezuela - \$117.50, Algeria - \$130 per barrel to break even as the economy has already lost more than $\$ 28$ billion as a result of the declining oil price. The Nigerian economy also lost about $\$ 42.5$ billion as the economy needs oil price to trade at about $\$ 123$ per barrel to balance its budget ${ }^{1}$. For the United States, the break-even oil price is on the average of $\$ 75$ per barrel while Russia has lost more than $\$ 150$ billion since oil price declined and needed oil price to be $\$ 98$ per barrel to balance the budget. In additition, Shyam, (2018) outlined that Venezuela needed \$216; Qatar - \$27; Saudi Arabia - \$88 and Russia - \$53 per barrel to balance their budgets.

It is evident that since 2014, when the current decline in oil prices began, the breakeven oil prices with which to balance budget by most of the oil exporting countries remain higher than the prevailing oil price and would likely widen the budget deficit gaps of most oil-exporters. Hence, it gave rise to the outlined research question of how Nigeria, Venezuela and Norway would be able to meet with the budgetary needs of their economies during periods of declining oil prices leading to decline in the oil revenue? The outlined questions captured in the questionnaires in Appendix A, B and C has enabled us to get the answers from the respondents through the Survey Monkey platform.

However, all the above studies mainly dealt with increasing oil price while the data analysed in all the oil price related studies reviewed are mainly secondary data. To the best of our knowledge, given all the related literature reviewed, it is evident that Survey data analysis of oil related studies, either increasing or decreasing oil shocks for oil-exporters, oil-importers, for developed, developing or emerging economies have widely received less attention and that is one of the major gaps that this study has closed.

\subsection{Methodology and Methods}

Every study is centred on data which is collected, analysed and interpreted to obtain useful information. Collection of data, therefore, is of great importance to any form of research. Primary data can be collected through diverse means such as questionnaires, interviews, focus group interviews, observation and case studies. The need for primary data depends largely on the nature of research to be carried out or on the nature of information needed by the researcher. In this study, the use of primary data is paramount to address the main research question raised from the literature, which could not be obtained through secondary means. The budget office and the ministry of finance of the three economies were identified as the appropriate research sample for the distribution of the questionnaire survey. The above is in conjunction with the main aim of the research,

\footnotetext{
${ }^{1}$ See Hayes, (2015)
} 
which is to ascertain how Nigeria, Venezuela and Norway attain to their budgetary needs during periods of declining oil revenues. Each of these government agencies take part in the budgetary decisions of these economies as the budget office prepares the budget with the collaboration of the ministry of finance for Nigeria, Venezuela and Norway. The choice of these economies is mainly due to their level of dependency on oil as a major source of revenue. Nigeria is a nation with abundant natural resources, oil and gas being the highest gifted mineral in the country (Adamu, 2015; Halid 2015). Consistently, Ademola et al. (2015) referred to oil as the dominant source of revenue for the Nigerian economy. On the other hand, Venezuela is an economy, which depends heavily on the oil sector as oil was traced back to the economy since the early $20^{\text {th }}$ century. Venezuela has the highest proven oil reserves in OPEC and the $9^{\text {th }}$ oil exporter in the world as oil accounts for about $96 \%$ of its total exports and more than half the country's gross domestic product. Crude oil fuels the Venezuelan economy and saturates all aspect of the society (The World Bank, 2016; Tong, 2016; Workman, 2016; OPEC Annual Statistical Bulletin 2018). Nevertheless, the Norwegian economy is greatly endowed with abundant natural resources such as forests, fish, hydrocarbon and other minerals. Norway's oil industry accounts for over $\$ 40$ billion yearly. The oil sector is highly relied on by the economy because it accounts for the largest portion of export earnings and close to 30\% of the administrative revenues (Recknagel 2016; 2016 CIA World Factbook). However, the primary data were collected through the questionnaires that were administered to the relevant government agencies and parastatals.

\subsection{Pilot Study}

It was necessary to carry out the pilot test of the designed questionnaires in order to correct some of the questions by employing some of the important inputs made by some of the respondents about the research. Pilot study gives the researcher the idea of what to expect from the respondents when sent out to the main research sample or population. Bryman, $(2016,2008)$ maintain that it is imperative to pilot test any research first, as this supports the evaluation of the validity of the questionnaire. It further enables the researcher to measure the reliability of the data, sourced through the questionnaires. It is also described as the pilot study as a small experiment, which is to be carried out before the formal study, in order to have prior knowledge of the research result. More so, pilot testing also aims at refining of the questionnaires, elimination of any difficulties while ensuring that the questions are comprehensible, effective and successful (De Vos, 1998).

However, a pilot study was carried out within the Graduate School, Abertay University Dundee, before distributing the questionnaires to the main targeted audience in the three countries under study. A total of 30 questionnaires were distributed while 23 were received with comments and suggestions. The remaining 7 could not be reached as they were not in school as at the period of collection. The feedback gotten from the pilot study helped immensely in the restructuring of the whole questions before distributing to the main targeted audience.

Some of the respondents from the pilot study suggested that the total number of questions should be reduced since they are aimed at addressing only one research question while some questions are repeated in different forms. As a result, the number of questions were reduced from 17 to 10 questions. Another comment from the pilot study was to employ 5 Likert scale formats, to include "Neutral". One of the reasons given is that some of the respondents may not have the idea of some of the questions. The suggestion was adopted as we now have 5 Likert scale formats: Strongly Agree, Agree, Neutral, Disagree and Strongly Disagree. Though, one of the respondents suggested a question to be included but that question was discarded as it is not within the purview of this study.

\subsection{Exploration of the Primary Data}

The analysis of data involves the cleansing, transformation and modelling of data to obtain meaningful information, which would be beneficial to policymakers. However, the primary data were analysed using SPSS Version 25 package.

The primary data were sourced from the budget office and ministry of finance of the countries under study, using questionnaires. From the literature, survey questionnaires were developed based on the kind of information needed to address the research question (Baruch and Holtom, 2008). The design was also adapted from other related studies like Mellor and Moore, (2014); International Budget Partnership, (2011) on "Guide to the open budget questionnaire: An explanation of the questions and the response options"; Revenue Watch index Questionnaire, (2009).

We also followed the guiding principles outlined by Sanchez and Goolsbee, (2010); Malhotra and Birks (2000) by designing questionnaires with the following characteristics:

- Straightforward questions that can be answered easily by the respondents, aimed at providing answers to the research questions.

- Clarity of the questions would help in reducing the response rate error.

- Suitable questions which would motivate the respondents to complete the questionnaires should be considered. 
- Sensitive questions that involve personal details of participants should be in the last part of the questionnaire. Although, personal details of respondents are not necessary for this study and as such, not included in the questionnaires.

Frankfort-Nachmias and Nachmias, (2008) outlined the three types of questions: Open-ended questions which allow the respondents to answer in their own words and encourages them to express their feelings, closedended questions which are easy and quick to answer and it involves a very straightforward analysis. The third type is the contingency questions, which are special-case closed-ended questions that apply to only a subgroup of respondents. For this study with a total of ten questions, we employed both the closed-ended questions and openended questions in the ratio of 2:1 (that is, eight closed-ended questions and two open-ended questions). All the questions aimed at addressing the issue of how Nigeria, Venezuela and Norway would attain to their budgetary needs during periods of declining oil revenues given that they are heavily relying on oil revenue. The questionnaires were designed on a 5-point Likert scale order to obtain data that are highly satisfactory and reliable (Mellor and Moore, 2014; Likert, 1932); the Likert scale is frequently used in most survey analysis and it is often considered to be of an excellent standard (Pescaroli, et al., 2020).

3.2.1 Sampling and Sampling Technique for this Study

Sampling is a technique that is used by researchers to select relatively smaller part of the population for the research. Sampling is necessary since it is not possible to test each member of the entire population under study. There are different types of sampling techniques that are employed for different survey research, such as probability and non-probability sampling. While probability sampling entails a sampling technique in which each member of the population has an equal chance of being chosen independently of other members of the population, a non-probability sampling technique is mainly based on the researcher's judgement (Sharma, 2017). Purposive sampling is a non-probability sampling technique, also can be referred to as judgmental, selective or subjective sampling. The selection of the sample to be studied relies on the researcher's judgement. This sampling technique provides the researcher with the justification of drawing conclusions and making a generalisation about the issue under consideration from the sample selected (Sharma, 2017).

However, for this study, purposive sampling was used in selecting our sample (sub-set of the population) because it enabled us to use our judgement to focus on the part of the population that would help us to gather the needed data for addressing the research question and which also helped us in drawing reasonable conclusion about the entire population. Although the judgemental component of the purposive sampling is the only major disadvantage when the judgement is not based on clear criteria. However, that limitation is overcome by ensuring that the data gathered from the Ministry of Finance and the Budget office of each of these countries where accurate information about the budget of the economies.

3.2.2 Questionnaire Administration and the Collection of Data

Since budgetary information of Nigeria, Venezuela and Norway is needed, the budget office and the ministry of finance of each of these countries were chosen as our sample. This decision was made because some of their roles are to manage the financial assets of the government, annual fiscal budget preparation and administration, proposal of sound monetary and fiscal policy, to issue adequate regulations for the execution of the budget, they report all the fiscal and economic plans of nations, implementation of the budget, keeping the financial records, debt management functions, business processes based on what is viewed as the best practice (Allen et al., 2015; Andrews 2013; Blommestein 2005).

However, Survey Monkey platform was used for administering and the collection of the questionnaires (through online). SurveyMonkey, an online survey development cloud-based is a tool, which enables researchers to launch any kind of survey project. This platform allows researchers to tailor the surveys according to the defined target audience. The Survey Monkey features are designed to help in conducting different types of surveys online which enable researchers to reach out to millions of respondents and at the same time, obtain real-time results.

The total number of senior workers in the budget office and ministry of finance in each of the economies are 340 (Nigeria), 230 (Venezuela) and 286 (Norway) (Norway Ministry of Finance, 2021; Amadeo, 2018; The National Budget, 2018; Udo, 2014). A total number of 600 questionnaires were distributed, 200 for each country while a total number of 375 were returned. Specifically, 138 responses were returned from Nigeria, 116 were returned from Venezuela while 121 were returned from Norway.

Purposive Sampling was used in selecting the sample given the fact that 200 is the common figure in each of these three nations. The number of senior workers in budget office and ministry of finance varied diversely across the nations (340 - Nigeria; 282 - Venezuela and 286 - Norway). The purposive sampling enabled us to use our judgement for the best selection criteria. More so, it is a comparative analysis in which all the three economies under study are treated equally. There are problems associated with using very small samples or very large samples. When a small sample is used, it increases the chances of assuming a false premise to be true or that of true premise to be false. On the other hand, using a sample larger than necessarily has its own effect. It is highly unethical to include the number above the population size, which could also lead to substantial increase of 
the analysis power thereby making what is insignificant to become significant (Faber and Fonseca, 2014). However, given the above effects of using small or large samples, we avoided using smaller or larger samples but rather chose the sample size which is common across the three countries.

3.2.3 The Response Rates for Nigeria, Venezuela and Norway

In recently statistical surveys, the response rates are the most widely cited metric (Montgomery et al., 2016). The response rate is calculated when the number of responses returned is divided by the total number of questionnaires administered (Sauro, 2011). Nigeria recorded a response rate of $69 \%$, while the response rate for Venezuela is $58 \%$ and $60.5 \%$ response rate for Norway, respectively. The response rates calculations for the primary data surveys are as presented in table 3.1 below:

Table 3.1 Response Rate (\%)

\begin{tabular}{|l|c|l|l|}
\hline Country & $\begin{array}{l}\text { Total number } \\
\text { of } \\
\text { Questionnaires } \\
\text { Administered }\end{array}$ & $\begin{array}{l}\text { Total Number of } \\
\text { Responses } \\
\text { Returned }\end{array}$ & Response Rate (\%) \\
\hline Nigeria & 200 & 138 & $(138 / 200) \times 100=69 \%$ \\
\hline Venezuela & 200 & 116 & $(116 / 200) \times 100=58 \%$ \\
\hline Norway & 200 & 121 & $(121 / 200) \times 100=60.5 \%$ \\
\hline Total & 600 & 375 & $(375 / 600) \times 100=62.5 \%$ \\
\hline
\end{tabular}

Source: Authors' Computation and design from plotted graphs 3.2.4 Graphs and Descriptive Statistics of the Primary Data

Graphs indicate the direction of the curves while the descriptive statistics summarise the collected data for easier understanding. The graphs showing the responses for each of the countries are as presented in graphs 3.1 (Nigeria), 3.2 (Venezuela) and 3.3 (Norway). More so, each of the graphs labelled Nig.1-Nig.8 represents the outcome for all the closed-ended questions for the Nigerian economy. Similarly, the graphs labelled Ven $1-$ Ven 8 , are the results for the Venezuelan economy while the graphs that ranged from Nor. 1 - Nor. 8 are the outcome for the Norwegian economy. The questions were analysed independently using SPSS Version 25 and showed graphically the percentage of each point on the Likert scale, which signifies the opinions of all the respondents about each of the question. The details of these results are presented in section 4.0 - Presentation and discussion of results. 
Figure 3.1 Graphs for Nigeria
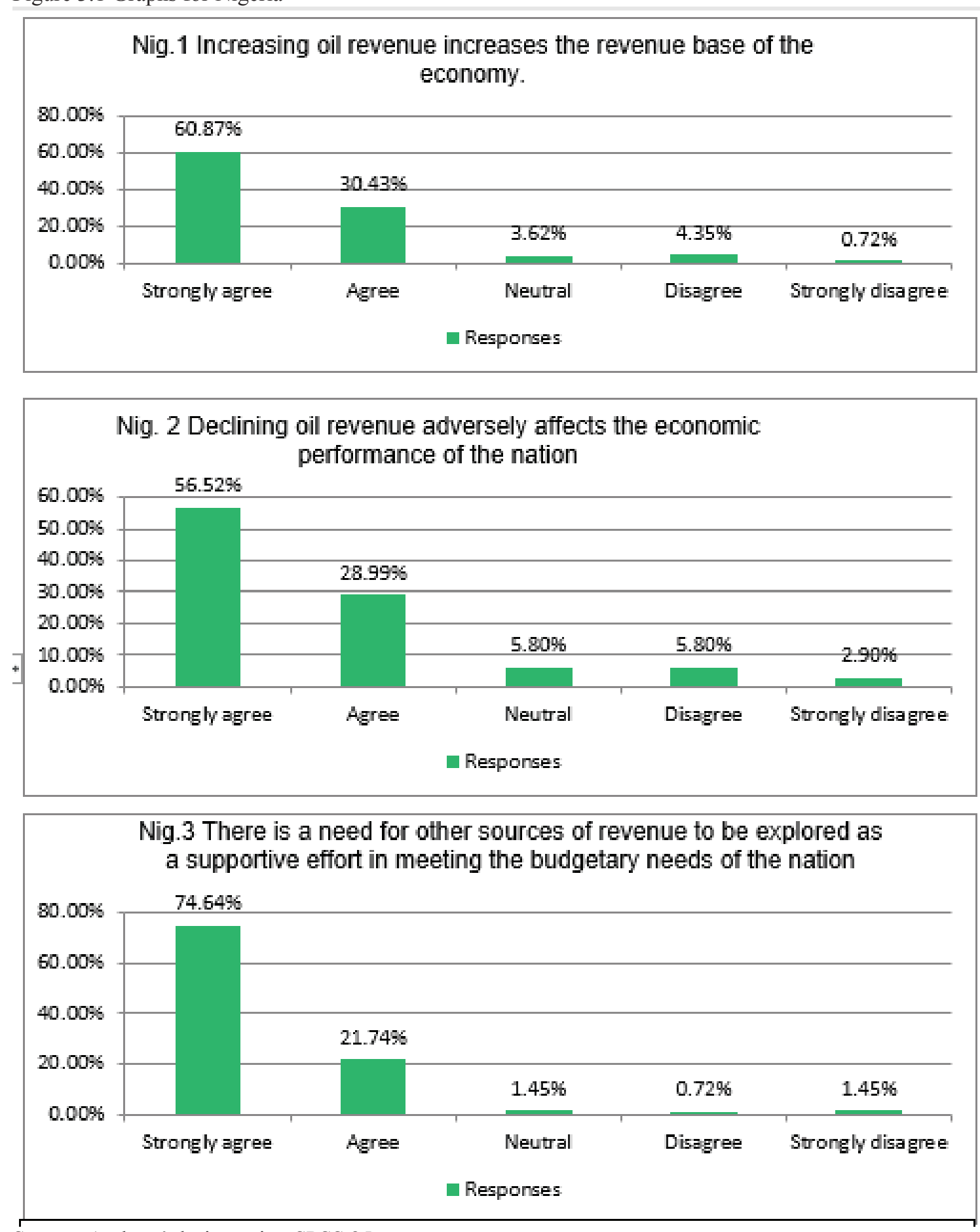

Source: Authors' design using SPSS 25 

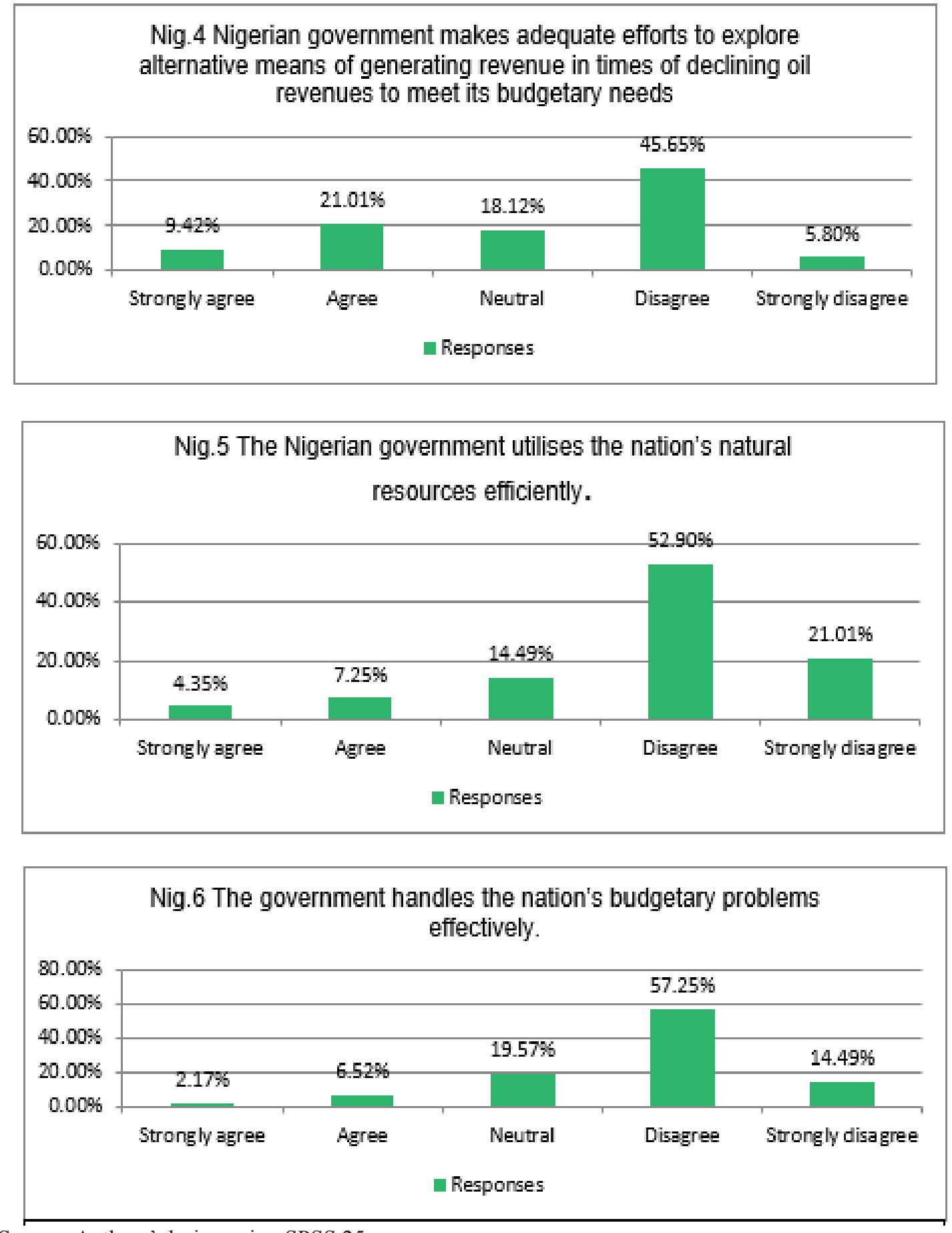

Source: Authors' design using SPSS 25 

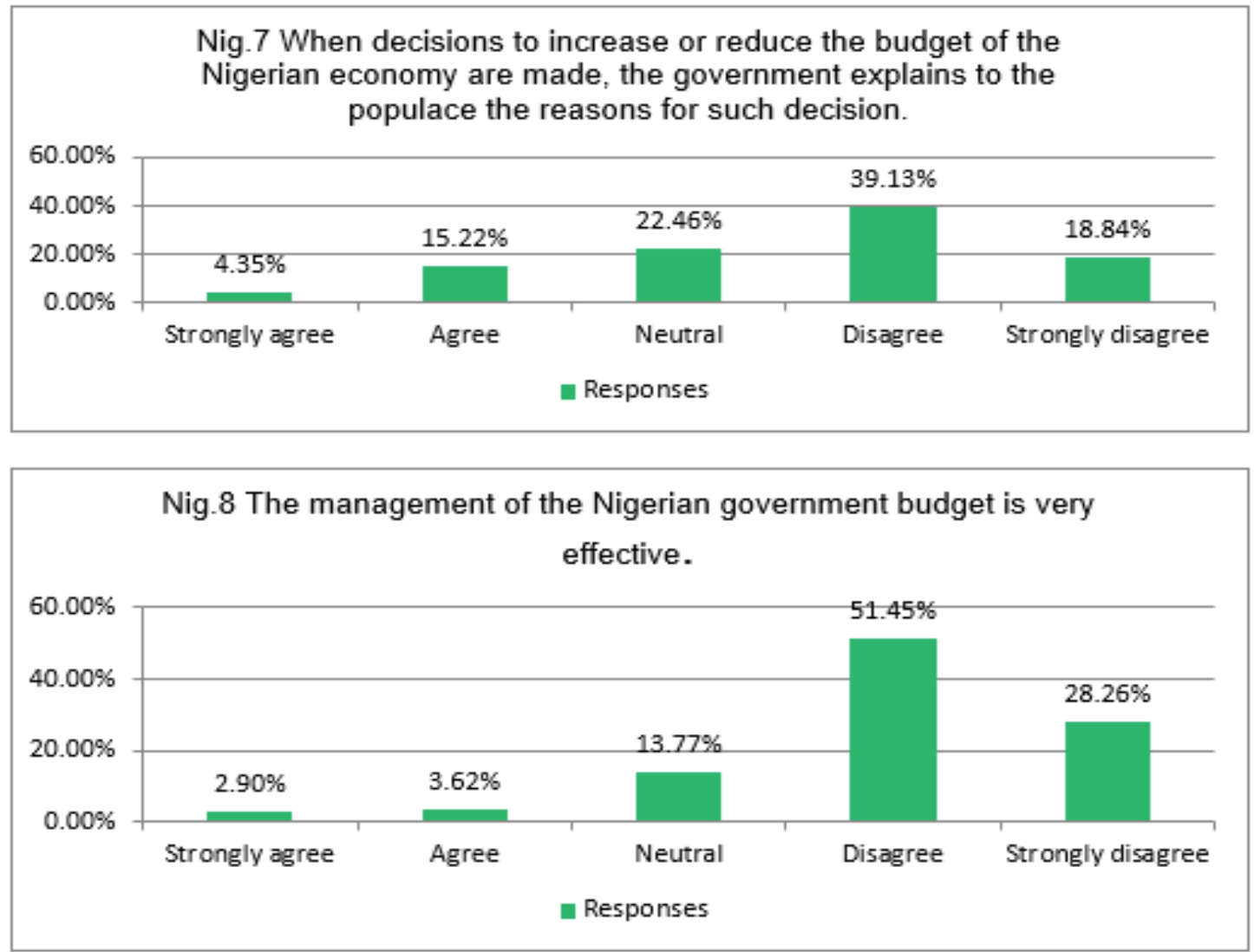

Source: Authors' design using SPSS 25

Table 3.3 Summary of graphs for Venezuela

\begin{tabular}{|c|c|c|c|c|c|c|}
\hline \multirow{2}{*}{ QUESTION } & STRONGLY & AGREE & NEUTRAL & DISAGREE & STRONGLY & TOTAL \\
\cline { 2 - 7 } & AGREE & $(\mathrm{A})$ & $(\mathrm{N})$ & $(\mathrm{D})$ & DISAGREE & $100 \%$ \\
\cline { 2 - 7 } & $(\mathrm{SA})$ & & & & $(\mathrm{SD})$ & \\
\hline 1 & 57.76 & 25.86 & 10.34 & 6.03 & 0 & 100 \\
\hline 2 & 64.66 & 20.69 & 11.21 & 2.59 & 0.86 & 100 \\
\hline 3 & 57.76 & 25.86 & 12.07 & 2.59 & 1.72 & 100 \\
\hline 4 & 5.17 & 8.62 & 17.24 & 35.34 & 33.62 & 100 \\
\hline 5 & 3.45 & 4.31 & 12.07 & 32.76 & 47.41 & 100 \\
\hline 6 & 2.59 & 3.45 & 15.52 & 23.28 & 55.17 & 100 \\
\hline 7 & 2.59 & 12.07 & 18.97 & 51.72 & 14.66 & 100 \\
\hline 8 & 1.72 & 3.45 & 11.21 & 25 & 58.62 & 100 \\
\hline
\end{tabular}

Source: Authors' design from plotted graphs using SPSS 25 
Figure 3.3 Graphs for Norway
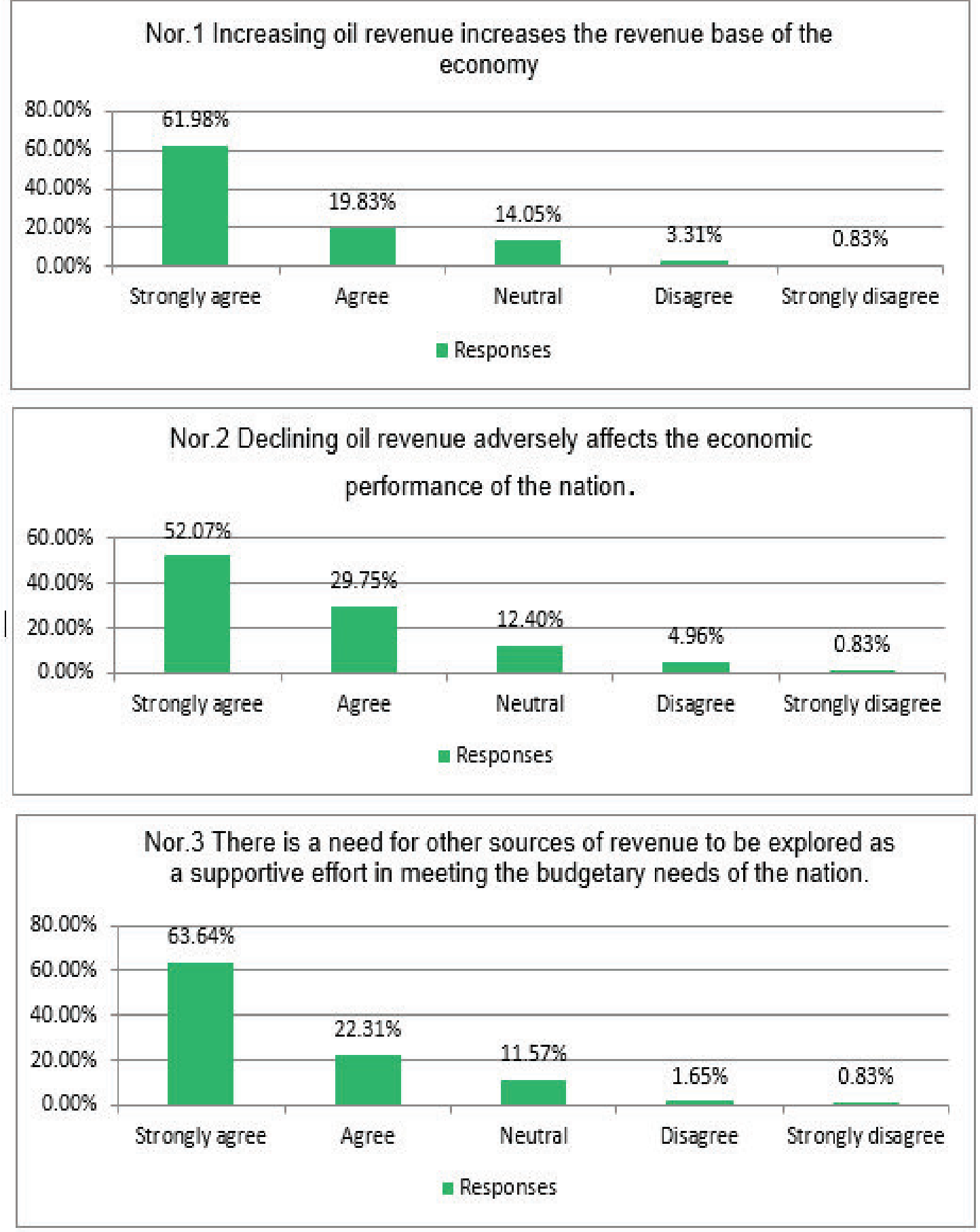

Source: Authors' design using SPSS 25 

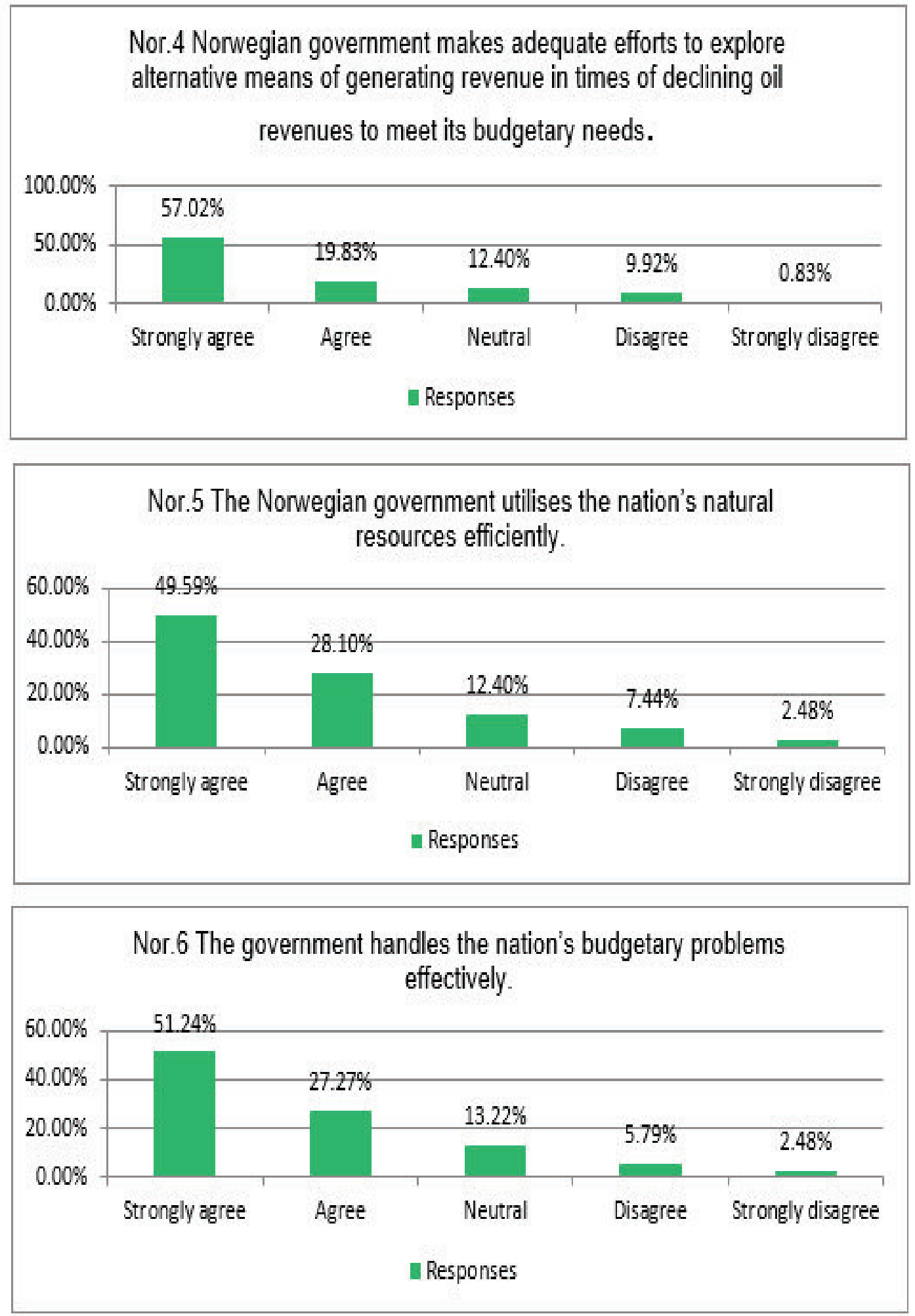

Source: Authors' design using SPSS 25 

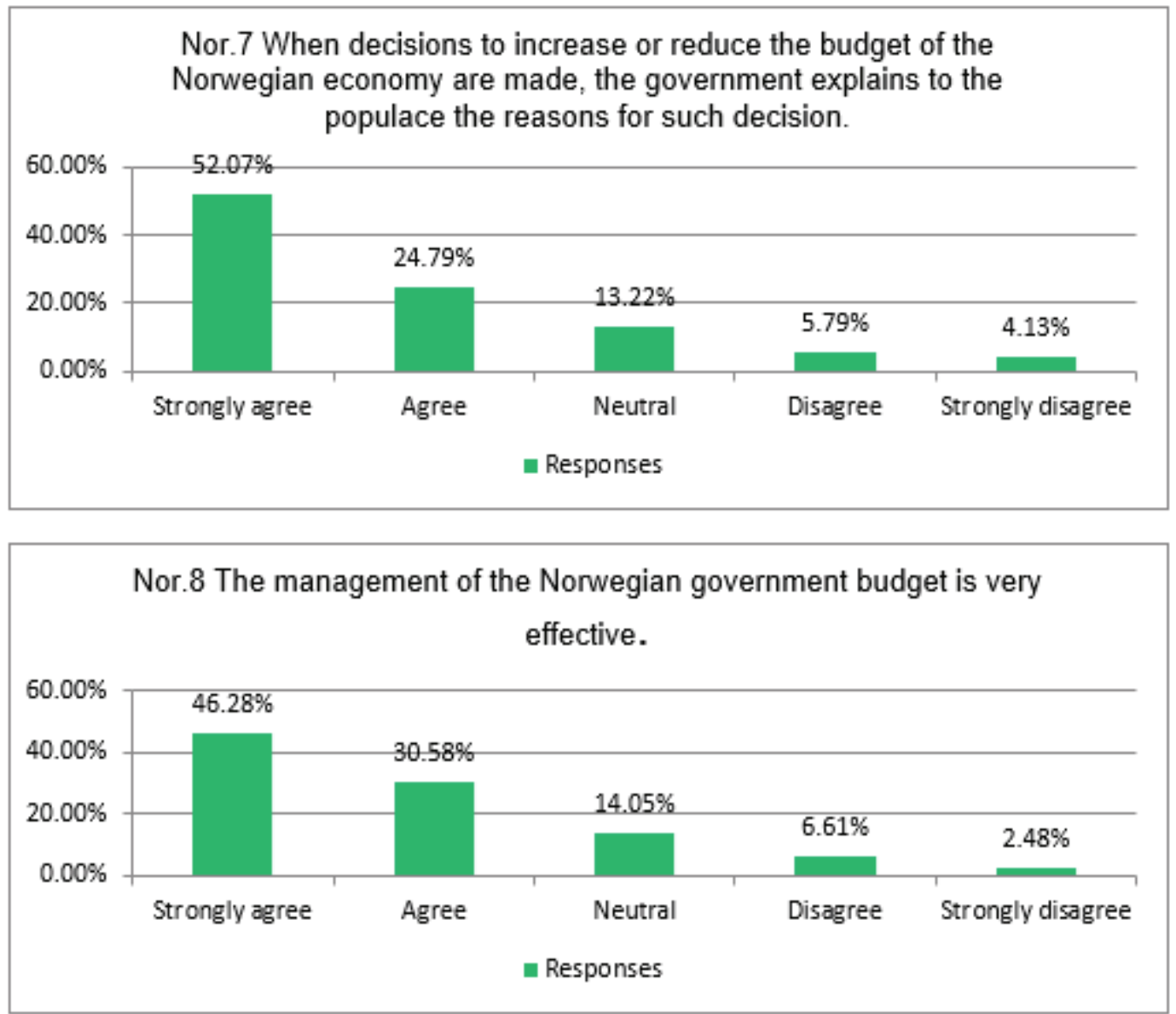

Table 3.4 Summary of graphs for Norway

\begin{tabular}{|c|c|c|c|c|c|c|}
\hline \multirow{2}{*}{ QUESTION } & STRONGLY & AGREE & NEUTRAL & DISAGREE & STRONGLY & TOTAL \\
\cline { 2 - 7 } & AGREE & (A) & (N) & (D) & DISAGREE & \multirow{2}{*}{$100 \%$} \\
\cline { 2 - 7 } & $(\mathrm{SA})$ & & & & $(\mathrm{SD})$ & \\
\hline 1 & 61.98 & 19.83 & 14.05 & 3.31 & 0.83 & 100 \\
\hline 2 & 52.07 & 29.73 & 12.4 & 4.96 & 0.83 & 100 \\
\hline 3 & 63.64 & 22.31 & 11.57 & 1.65 & 0.83 & 100 \\
\hline 4 & 57.02 & 19.83 & 12.4 & 9.92 & 0.83 & 100 \\
\hline 5 & 49.59 & 28.1 & 12.4 & 7.44 & 2.48 & 100 \\
\hline 6 & 51.24 & 27.27 & 13.22 & 5.79 & 2.48 & 100 \\
\hline 7 & 52.07 & 24.79 & 13.22 & 5.79 & 4.13 & 100 \\
\hline 8 & 46.28 & 30.58 & 14.05 & 6.61 & 2.48 & 100 \\
\hline
\end{tabular}

Source: Authors' design from plotted graphs using SPSS 25

3.2.5 Open-Ended Questions and the Dominant Responses

The survey questions contain eight closed-ended questions and two open-ended questions. The outcome of the open-ended questions is outlined in tables 3.5, table 3.6 and table 3.7 while all the results are presented in section 4.0. Nonetheless, from the gap identified through the various literature reviewed, the primary data, in general, are gathered in order to provide answers to the research question that has been raised and also to fill the identified gaps. It also aims at supplementing the findings obtained from the secondary data analyses.

Unlike the data gathered from the closed-ended questions, the nature and the structure of all the information gathered from the open-ended questions do not require any form of transformation because they are straightforward answers, which greatly represents the opinions of the respondents. For each of the responses from the 
three economies, the dominant responses were selected from which conclusions were drawn. The confidentiality and the anonymity of all the respondents are highly conserved. Below are the two questions and the corresponding dominant responses for Nigeria, Venezuela and Norway.

Table 3.5 Dominant Responses from the respondents in Nigerian

\begin{tabular}{|c|c|c|c|c|c|}
\hline $\begin{array}{l}\text { Question 9: How does } \\
\text { Nigeria attain its budgetary } \\
\text { needs during the periods of } \\
\text { declining oil revenues? }\end{array}$ & $\begin{array}{l}\text { Freque } \\
\text { ncy }\end{array}$ & (\%) & $\begin{array}{l}\text { Question 10: What does } \\
\text { the Nigerian government } \\
\text { need to do to improve its } \\
\text { revenue base and } \\
\text { budgetary performance in } \\
\text { times of declining oil } \\
\text { revenue? }\end{array}$ & $\begin{array}{l}\text { Frequ } \\
\text { ency }\end{array}$ & $(\%)$ \\
\hline Responses & & & Responses & & \\
\hline $\begin{array}{l}\text { "Internal and external } \\
\text { borrowing." }\end{array}$ & 48 & 34.8 & $\begin{array}{l}\text { "Diversification and good } \\
\text { governance." }\end{array}$ & 51 & 37.0 \\
\hline "Dependence on foreign aid." & 28 & 20.3 & $\begin{array}{l}\text { "Restore security and } \\
\text { fight insecurity } \\
\text { problems." }\end{array}$ & 23 & 16.7 \\
\hline $\begin{array}{l}\text { "Cutting civil servants' } \\
\text { salaries to percentages" }\end{array}$ & 23 & 16.7 & $\begin{array}{l}\text { "Develop the agricultural } \\
\text { sector" }\end{array}$ & 21 & 15.2 \\
\hline $\begin{array}{l}\text { "Relying on money recovered } \\
\text { from looters" }\end{array}$ & 21 & 15.2 & $\begin{array}{l}\text { "Improvement of the } \\
\text { other sectors." }\end{array}$ & 20 & 14.5 \\
\hline $\begin{array}{l}\text { "External loans from IMF, } \\
\text { Paris club etc." }\end{array}$ & 10 & 7.2 & $\begin{array}{l}\text { "Efficient Resource } \\
\text { Management and } \\
\text { effective utilization of } \\
\text { government funds." }\end{array}$ & 18 & 13.0 \\
\hline Others & 8 & 5.8 & Others & 5 & 3.6 \\
\hline Total & 138 & $100 \%$ & Total & 138 & $100 \%$ \\
\hline
\end{tabular}

Source: Authors' design from questionnaire responses

Table 3.6 Dominant Responses from the respondents in Venezuela

\begin{tabular}{|c|c|c|c|c|c|}
\hline $\begin{array}{l}\text { Question 9: How does } \\
\text { Venezuela attain its } \\
\text { budgetary needs during } \\
\text { the periods of declining } \\
\text { oil revenues? }\end{array}$ & Frequency & (\%) & $\begin{array}{l}\text { Question 10: What does } \\
\text { the Venezuelan } \\
\text { government need to do to } \\
\text { improve its revenue base } \\
\text { and budgetary } \\
\text { performance in times of } \\
\text { declining oil revenue? }\end{array}$ & Frequency & $(\%)$ \\
\hline Responses & & & Responses & & \\
\hline $\begin{array}{l}\text { "Borrowing and } \\
\text { seigniorage." }\end{array}$ & 47 & 40.5 & $\begin{array}{l}\text { "Diversify the economy } \\
\text { and reduce over-reliance } \\
\text { on oil." }\end{array}$ & 51 & 44.0 \\
\hline $\begin{array}{l}\text { "The government } \\
\text { borrow to finance their } \\
\text { deficits." }\end{array}$ & 21 & 18.1 & $\begin{array}{l}\text { "Investment in other } \\
\text { sectors." }\end{array}$ & 18 & 15.5 \\
\hline $\begin{array}{l}\text { "Dependence on } \\
\text { foreign aid." }\end{array}$ & 18 & 15.5 & $\begin{array}{l}\text { "Reduce over-reliance } \\
\text { on oil." }\end{array}$ & 15 & 12.9 \\
\hline $\begin{array}{l}\text { "Loans from both } \\
\text { internal and external } \\
\text { sources." }\end{array}$ & 15 & 12.9 & $\begin{array}{l}\text { "Development of human } \\
\text { capacity and wealth } \\
\text { creation." }\end{array}$ & 13 & 11.2 \\
\hline $\begin{array}{l}\text { "Borrowing from } \\
\text { reserves." }\end{array}$ & 10 & 8.6 & $\begin{array}{l}\text { "Avoid wrong } \\
\text { administrative } \\
\text { decisions." }\end{array}$ & 12 & 10.3 \\
\hline Others & 5 & 4.3 & Others & 7 & 6.0 \\
\hline Total & 116 & $100 \%$ & Total & 116 & $100 \%$ \\
\hline
\end{tabular}

Source: Authors' design from questionnaire responses 
Table 3.7 Dominant Responses from the respondents in Norway

\begin{tabular}{|c|c|c|c|c|c|}
\hline $\begin{array}{l}\text { Question 9: How does } \\
\text { Norway attain its } \\
\text { budgetary needs during } \\
\text { the periods of declining } \\
\text { oil revenues? }\end{array}$ & $\begin{array}{c}\text { Freque } \\
\text { ncy }\end{array}$ & $(\%)$ & $\begin{array}{l}\text { Question 10: What does the } \\
\text { Norwegian government need } \\
\text { to do to improve its revenue } \\
\text { base and budgetary } \\
\text { performance in times of } \\
\text { declining oil revenue? }\end{array}$ & $\begin{array}{c}\text { Freque } \\
\text { ncy }\end{array}$ & (\%) \\
\hline Responses & & & Responses & & \\
\hline $\begin{array}{l}\text { "Sovereign Wealth Fund } \\
\text { where oil revenue } \\
\text { excess is kept for future } \\
\text { use." }\end{array}$ & 50 & 41.3 & $\begin{array}{l}\text { "Continue to diversify the } \\
\text { revenue base of the } \\
\text { economy." }\end{array}$ & 48 & 40.0 \\
\hline $\begin{array}{l}\text { "The Pension Fund is } \\
\text { used." }\end{array}$ & 19 & 15.7 & $\begin{array}{l}\text { "Adjustment of the policy to } \\
\text { suit the current situation and } \\
\text { continue with their good } \\
\text { governance" }\end{array}$ & 20 & 16.5 \\
\hline $\begin{array}{l}\text { "Reserves of the } \\
\text { economy." }\end{array}$ & 17 & 14.0 & $\begin{array}{l}\text { "More investment in the } \\
\text { economy because the } \\
\text { economy is already doing } \\
\text { well." }\end{array}$ & 18 & 14.9 \\
\hline $\begin{array}{l}\text { "From the countries } \\
\text { reserves." }\end{array}$ & 16 & 13.2 & $\begin{array}{l}\text { "Income tax reduction to } \\
\text { encourage foreign } \\
\text { investment." }\end{array}$ & 16 & 13.2 \\
\hline "Oil reserves." & 12 & 10.0 & $\begin{array}{l}\text { "Continue to explore other } \\
\text { sectors of the economy } \\
\text { especially the gas sector" }\end{array}$ & 11 & 9.1 \\
\hline Others & 7 & 5.8 & Others & 8 & 6.6 \\
\hline Total & 121 & $100 \%$ & Total & 121 & $100 \%$ \\
\hline
\end{tabular}

Source: Authors' design from questionnaire responses

\subsection{Presentation and Discussion of Results}

All the primary data, sourced through the questionnaires for Nigeria, Venezuela and Norway are presented below:

\subsection{Data Presentation for Nigeria}

Table 3.2 presents the summary of the graphs for the Nigerian economy, which summarised all the results obtained from the closed-ended questions. The 5-point Likert scale was used to assess the respondent's opinions about the questions presented while Table 3.5 is the dominant responses from the two open-ended questions, which enables the respondents to present their opinion in their own words and to offer them the opportunity to air their views about the questions. Similarly, table 4.1 below is derived from table 3.2 for easy understanding and interpretation as we merged the "Strongly Agree" (SA) + "Agree" (A) = "Agreed" (A) while "Strongly Disagree" (SD) + "Disagree" (D) = "Disagreed" (D). The same process was applied to table 4.2 (Venezuela) and table 4.3 (Norway).

Question1 seeks to find out whether increasing oil revenue increases the revenue base of the Nigerian economy. The results reveal that 91.3 percent agreed, while 5.07 percent disagreed, and the remaining 3.62 percent were neutral. This is very reasonable since Nigeria as an oil-exporting nation is highly dependent on oil for over 98 percent of its exports. This result is also highly consistent with the findings from the secondary data analyses which revealed that a per centage increase in oil price would increase oil revenue by 0.804 percent while a percentage increase in one period lag of oil price will also increase the oil revenue by 0.359 percent. Similarly, the result reveals that a one percent decline in oil price will lead to a corresponding decline in oil revenue of 0.292 percent. However, this result indicates that the oil price is directly proportional to oil revenue in Nigeria (Abubakar et al., 2016; Joshua et al., 2016; Akinlo, 2012).

Question 2 is the direct opposite of the above, which seeks to find out if declining oil revenue adversely 
affects the economic performance of the Nigerian economy. 85.51 percent agreed while 8.7 percent disagreed, and 5.8 remain neutral. The result shows that declining oil revenue adversely affects the economic performance of the Nigerian economy and it is highly consistent with the findings from the secondary data. However, 96.38 percent of the respondents agreed that there is a need for other sources of revenue to be explored as a supportive effort in meeting the budgetary needs of the nation as indicated in question 3. From this result, the respondents opine the need for the Nigerian economy to widen their horizon by expanding the nation's revenue base by giving attention to other sectors of the economy other than the oil sector. It calls for a way to reduce overdependence on oil which is always the case since the discovery of oil.

Conversely, questions 4, 5, 6, 7 and 8 followed the same trend as most of the respondents disagreed in each case as indicated in the table 4.1 below. Specifically, 51.45 percent of the respondents disagreed that the Nigerian government are not making adequate efforts to explore alternative means of generating revenues in times of declining oil revenues to meet its budgetary needs while 30.45 percent agreed to that. It is consistent with the result obtained in question 3 above, as there is every need for the expansion of other revenue base in Nigeria. Also, 71.74 percent of the respondents disagreed that the government utilise the nations natural resources efficiently given that Nigeria is endowed with other natural resources Abubakar et al., (2016); Hassan (2013). 71.74 percent disagreed that the government handles the nation's budgetary problems effectively while 79.71 percent disagreed that the management of the budget is very effective. This result is consistent with the findings of Nwankpa and Okeke, (2017); Igbara et al., (2016) and Olaoye (2014); they revealed that the Nigerian budgetary processes are characterised by indiscipline, deficient governance and implementation crises which have prevented the actualisation of the long-expected goals. They advocate for a disciplined-based process in the Nigerian budgetary system. However, there is a need for effective management of the Nigerian budgetary system as also outlined by Sam-Tsokwa and Ngara, (2016) and Ekeocha, (2012).

In addition, results from Table 3.5 reveal the dominant responses for questions 9 and ten which aim at finding out how Nigeria attain its budgetary needs during periods of declining oil revenues and what the government need to do to improve the revenue base and budgetary performance in times of declining oil revenue. However, the dominance response obtained for question 9 is that the government resort to internal and external borrowing in order to finance the budget deficits during the periods of declining oil revenue. Hence, this outcome has provided the answer to our research question, raised from the literature: "How does Nigeria attain its budgetary needs during the periods of declining oil revenues?"

Nevertheless, resorting to borrowing of any kind is not the best given that most loans are collected based on the interest to be paid subsequently, which would likely increase the debt burden in the economy. Debt servicing will also affect the nation's revenue base adversely. This result is also in consonance with the findings of Nwoba et al., (2017) and Paiko, (2012). To improve the revenue base of the economy, it is highly recommended that Nigeria diversifies its revenue base, restore security which will attract foreign investors, develop the agricultural sector which was the mainstay of the economy before the discovery of oil, manage the other natural resources efficiently and utilise government funds effectively.

Table 4.1 Frequency Distribution Table for Nigeria

\begin{tabular}{|c|c|c|c|c|c|}
\hline \multirow[b]{2}{*}{ QUESTION } & \multirow{2}{*}{$\begin{array}{c}\text { MEAN } \\
\& \\
\text { MEDIAN }\end{array}$} & \multirow{2}{*}{$\begin{array}{c}\mathrm{SA}+\mathrm{A} \\
(\mathrm{AGREED}) \\
(\%)\end{array}$} & \multirow{2}{*}{$\begin{array}{l}\text { NEUTRAL } \\
\text { (\%) }\end{array}$} & $D+S D$ & \multirow{2}{*}{$\begin{array}{l}\text { MAXIMUM } \\
\& \\
\text { MINIMUM }\end{array}$} \\
\hline & & & & $\begin{array}{c}\text { (DISAGREED) } \\
(\%)\end{array}$ & \\
\hline 1 & 5.0 & 91.3 & 3.62 & 5.07 & SA \\
\hline 2 & 5.0 & 85.51 & 5.8 & 8.7 & SA \\
\hline 3 & 5.0 & 96.38 & 1.45 & 2.17 & SA \\
\hline 4 & 2.0 & 30.43 & 18.12 & 51.45 & D \\
\hline 5 & 2.0 & 11.6 & 14.49 & 73.91 & $\mathrm{D}$ \\
\hline 6 & 2.0 & 8.69 & 19.57 & 71.74 & $\mathrm{D}$ \\
\hline 7 & 2.0 & 19.57 & 22.46 & 57.97 & D \\
\hline 8 & 2.0 & 6.52 & 13.77 & 79.71 & D \\
\hline
\end{tabular}

Source: Authors' compilation from plotted graphs using SPSS 25

\subsection{Data Presentation for Venezuela}

For the Venezuelan economy, table 3.3 summarised all the results obtained from the closed-ended questions while the dominant responses from the open-ended questions for the Venezuelan economy are presented in table 3.6. From table 4.2 below, Venezuela obtained similar results like that of the Nigerian economy in all the 
questions $1-8$. Specifically, in questions 1,2 and 3, the response rates of the agreed respondents are 83.62 percent, 85.35 percent and 83.62 percent respectively as against 6.03 percent, 3.45 percent and 4.31 percent of the respondents who disagreed with the questions. The results indicate that Venezuela, as an oil-exporting nation, increases its revenue base with the increase in oil revenue while declining oil revenue adversely affects economic performance. This result is very reasonable because the literature reveals that Venezuela relies so much on oil revenue for over 96 percent of its revenue and as such would be affected either positively or negatively with the fluctuations in oil price. The outcome also supports the need for the Venezuelan economy to discover other sources of revenue apart from oil by developing other sectors of the economy and widening the revenue base. The results are consistent with our results from the secondary data analyses and in consonance with the findings of Monaldi, (2015).

On the contrary, the response rates for questions 4, 5, 6, 7 and 8 are 13.79 percent, 7.76 percent, 6.04 percent, 14.66 percent and 5.17 percent respectively agreed as against the disagreed response rates of 68.96 percent, 80.17 percent, 78.45 percent, 66.38 percent and 83.62 percent. The results imply that the Venezuelan government are not making adequate efforts in exploring alternative means of generating revenue to meet its budgetary needs in times of declining oil revenue. It also implies that the government are not utilising the nation's natural resources efficiently and not handling the nation's budgetary problems effectively. The result further reveals that the management of Venezuela's government budget is not effective. The above outcome is also consistent with the studies of Monaldi, (2015), Holden, (2011), Weisbrot and Sandoval, (2008).

Furthermore, table 3.6 presents the dominant responses from the open-ended questions 9 and 10 which seeks the information about how Venezuela attain its budgetary needs during the periods of declining oil revenues and what the economy needs do to improve its revenue base during periods of economic crisis. Just like the outcome obtained for the Nigerian economy, the dominant responses indicate that during periods of declining oil revenue, the Venezuelan government engage in borrowing to finance their budget deficits. They also resort to seigniorage, a situation where the economy spends to produce money used in running the affairs of the nation which often result to economic losses for Venezuela even though the cost of producing the currency is always less than the market value (Diego, 2018). However, this has answered the research question raised from the literature: "How does Venezuela attain its budgetary needs during the periods of declining oil revenues?"

These results are consistent with the studies of Diego, (2018a; 2018b); Ellis, (2017) which reveal that there is serious economic and political instability in Venezuela, combined with very high debt profile as the nation relies on the International Monetary Fund (IMF) for financial assistance. However, the economy needs also to widen its horizon as diversification is the watchword from most of the respondents regarding what the country needs do to improve its revenue base during the periods of declining oil revenue. There is also every need to reduce its dependence on oil by supporting other sectors of the economy.

Table 4.2 Frequency Distribution Table for Venezuela

\begin{tabular}{|c|c|c|c|c|c|}
\hline \multirow[b]{2}{*}{ QUESTION } & \multirow{2}{*}{$\begin{array}{c}\text { MEAN } \\
\& \\
\text { MEDIAN }\end{array}$} & \multirow{2}{*}{$\begin{array}{c}\mathrm{SA}+\mathrm{A} \\
\text { (AGREED) } \\
(\%)\end{array}$} & \multirow[b]{2}{*}{$\begin{array}{c}\text { NEUTRAL } \\
(\%)\end{array}$} & $D+S D$ & \multirow{2}{*}{$\begin{array}{l}\text { MAXIMUM } \\
\& \\
\text { MINIMUM }\end{array}$} \\
\hline & & & & $\begin{array}{c}\text { (DISAGREED) } \\
(\%)\end{array}$ & \\
\hline 1 & 5.0 & 83.62 & 10.34 & 6.03 & SA \\
\hline 2 & 5.0 & 85.35 & 11.21 & 3.45 & SA \\
\hline 3 & 5.0 & 83.62 & 12.07 & 4.31 & SA \\
\hline 4 & 2.0 & 13.79 & 17.24 & 68.96 & D \\
\hline 5 & 1.0 & 7.76 & 12.07 & 80.17 & SD \\
\hline 6 & 1.0 & 6.04 & 15.52 & 78.45 & SD \\
\hline 7 & 2.0 & 14.66 & 18.97 & 66.38 & $\mathrm{D}$ \\
\hline 8 & 1.0 & 5.17 & 11.21 & 83.62 & SD \\
\hline
\end{tabular}

Source: Authors' compilation from plotted graphs using SPSS 25

\subsection{Data Presentation for Norway}

The summary of the graphs (closed-ended questions) for the Norwegian economy is presented in table 3.4, while the dominant responses from the open-ended questions are presented in table 3.7. The results for the Norwegian economy as shown in Table 4.3 below indicate that all the respondents agreed to all the questions 1 to 8 with very high response rates for each of the questions as against the response rates for the disagreed column.

However, these outcomes signify that increasing oil price affects the oil revenue positively and affects it negatively when the oil price falls. They also agree that there is still a need for more sources of revenue to be 
explored in Norway to continue to support the economy during periods of declining oil revenues. This also shows that Norway truly depends on oil revenue for over half of its exports as revealed in the literature and through the studies of Buvarp, (2015); Holden, (2011). The above result is also consistent with our findings from the secondary data analyses.

In addition, the results for questions $4,5,6,7$ and 8 of the Norwegian economy differ significantly from the results obtained for Nigeria and Venezuela. Table 4.3 reveals that the respondents agreed to all the questions with 76.85 percent, 77.69 percent, 78.51 percent, 76.86 percent and 76.86 percent respectively for question 8 . However, these contrary results of Norway relative to those of Nigeria and Venezuela signify that there is still need for the Norwegian economy to continue to explore other sources of revenue other than oil to enable it to meet the budgetary needs of the nations during periods of declining oil revenues. The results also show that Norway makes adequate effort to explore alternative means of generating revenues and are utilising the nation's natural resources efficiently, also managing its budgetary process effectively. These results have confirmed our findings from the literature and consistent with the studies of Moses and Letnes, (2017); Buvarp, (2015); Koranyi, (2014).

The dominant responses for the Norwegian economy presented in Table 3.7 reveal that during periods of declining oil revenue, Norway does not resort to borrowing like Nigeria and Venezuela but rather finance their budgets through its Sovereign Wealth Fund and the government's Pension Funds. Hence, this has provided the answer to the research question: 'How does Norway attain its budgetary needs during periods of declining oil revenues'?

It was further revealed that Norway could continue to improve its revenue base by continuous diversification of other sectors of the economy, through the adjustment of its policy to suit the current situation. Most of the responses have the word "continue to" which shows that the respondents believe that the economy has been doing well and needed to keep it on. The results are also consistent with the literature and with the findings of Buvarp, (2015) and Holden, (2011). The studies reveal that even as oil is the backbone of the Norwegian economy, during periods of increasing oil price which increase their revenue base, Norway does not spend more than 4 per cent of its oil revenue while the rest are being saved for the future generations and periods of economic crises. Norway tries to avoid the paradox of plenty and is not having the resource curse syndrome that befalls most economies that are blessed abundantly with natural resources.

Table 4.3 Frequency Distribution Table for Norway

\begin{tabular}{|c|c|c|c|c|c|}
\hline \multirow[b]{2}{*}{ QUESTION } & \multirow{2}{*}{$\begin{array}{c}\text { MEAN } \\
\& \\
\text { MEDIAN }\end{array}$} & \multirow{2}{*}{$\begin{array}{c}\mathrm{SA}+\mathrm{A} \\
\text { (AGREED) } \\
(\%)\end{array}$} & \multirow{2}{*}{$\begin{array}{l}\text { NEUTRAL } \\
\text { (\%) }\end{array}$} & $D+S D$ & \multirow{2}{*}{$\begin{array}{l}\text { MAXIMUM } \\
\& \\
\text { MINIMUM }\end{array}$} \\
\hline & & & & $\begin{array}{c}\text { (DISAGREED) } \\
(\%)\end{array}$ & \\
\hline 1 & 5.0 & 81.81 & 14.05 & 4.14 & SA \\
\hline 2 & 5.0 & 81.8 & 12.4 & 5.79 & SA \\
\hline 3 & 5.0 & 85.95 & 11.57 & 2.48 & SA \\
\hline 4 & 5.0 & 76.85 & 12.4 & 10.75 & SA \\
\hline 5 & 5.0 & 77.69 & 12.4 & 9.92 & SA \\
\hline 6 & 5.0 & 78.51 & 13.22 & 8.27 & SA \\
\hline 7 & 5.0 & 76.86 & 13.22 & 9.92 & SA \\
\hline 8 & 5.0 & 76.86 & 14.05 & 9.09 & SA \\
\hline
\end{tabular}

Source: Authors' compilation from plotted graphs using SPSS 25

The findings from the primary data for Nigeria, Venezuela and Norway agree with the theories of budgetary decision making of oil revenue decline which assume that decision-makers have all the necessary information at their disposal which would enable them to make policy choices to determine the budget of the nations. The budget makers are assumed to think and act rationally about the future and are expected to use the previous decisions to determine the government's current budget. The theory further argues that decision making in any society is highly complex at all times and requires the development of a shortcut which would aid in facilitating decision making in any society. The declining oil price is affecting all the oil-exporting countries, but it is so glaring that the Norwegian economy acts differently regarding its management of the oil rent and are exempted from the resource curse syndrome which befalls most of the oil-exporting countries as supported by (Holden, 2011). The budget makers need to understand the impact of the declining oil revenues on their economic performance which would aid them to make policy choices that would help the nation function effectively like those of the Norwegian economy. 


\subsection{Proposed Economic Model}

Figure 4. 1 Proposed Economic Model for Nigeria and Venezuela

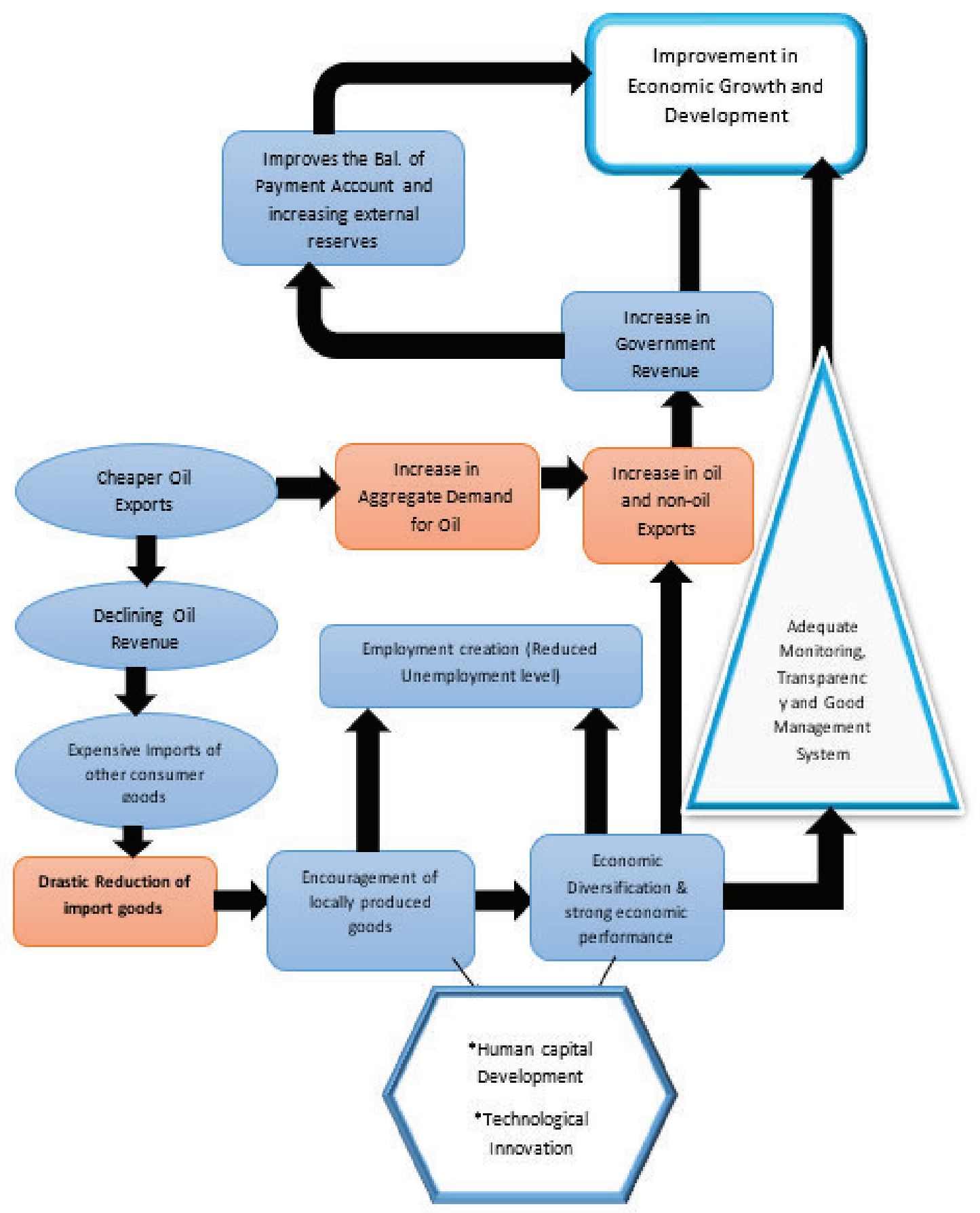

Source: Authors' design

An economic model is a simplified way of explaining the real world and its complex nature, which is often too difficult to understand literally. Economic models are usually subjective as different economists have different views and different judgements regarding the interpretation of what reality entails (Ouliaris, 2018). Also, Basu, (2009) referred to a model building in economics as the fruitful area of economics, which is designed to solve real-world problems by the use of all available methods without distinctions. Economic models are the primary tools economists employ in explaining economic issues or in making predictions about economic problems and solutions. This could be applied using words, mathematics or visually/graphically as the case may be. An economic model could also be referred to as a simplified structure that describes the workings of the economy, given that the world and its settings are too complex with too many data. An economic model is therefore regarded as a very simplified version of the real world as it helps us understand better how the 
economy works through the interaction of different variables. It is often designed to produce testable hypotheses about economic behaviours. Milton Friedman, among other economists, contend that economic models cannot just be tested by inquiring into the reality of its assumptions. These economists conclude that the validity of any economic model can be tested when it is capable of explaining and forecasting real-world activities. Friedman maintains that the ultimate test of any economic model is when it is faced with the data from the economy (Nicholson, 2007). However, the above economic model is developed for both the Nigeria, Venezuela and other similar countries that rely so much on oil revenue, aimed at closing the revenue gaps in these highly oildependent nations. The Norwegian economy already has an existing model which is working so effectively and as such do not need the above designed economic model.

Nevertheless, the starting point of this model, is the cheap oil export, due to the declining oil price. The cheap oil exports led to the declining oil revenues, hence, the inability of these nations to meet with the fiscal needs of the economies. The weak exchange rate amid the low oil revenue makes import of consumer goods to be more expensive while increasing the aggregate demand for oil. The first law of demand is obeyed at this point which states that at higher prices, lower quantity of the commodity in question is demanded and the lower the price, the higher the quantity of the product demanded and as such, price and quantity demanded are inversely related (Hutchinson, 2016).

The expensive imports metamorphose into the drastic reduction of import goods which should in-turn encourage the production of locally manufactured products. This would lead to economic diversification whereby the economies are shifted away from a single product source of revenue (for example, oil) to multiple sources of revenue by developing and investing on other sectors of the economies other than oil. For instance, in the late 1960s, agriculture has been the primary source of revenue for Nigeria before the discovery of oil as the nation is blessed with good fertile lands. Agriculture contributes more than $65 \%$ to the Gross Domestic Product of Nigeria in the 1960s but continuously declined to $48 \%$ in the 1970 s, $20 \%$ in 1980 and further to $19 \%$ in 1985 due to the discovery of oil and economic mismanagement (Ekperiware and Olomu, 2015). Chukwuma (2018) also contends that agriculture and solid minerals contributed over $90 \%$ to Nigeria's economic growth before the discovery of oil. Nigeria is endowed with other natural resources such as Coal, Bitumen, Iron Ore, Gypsum, Gold, Talc, Lead/Zinc, Bentonite and Barite, Gemstones, Kaolin, Rock Salt, Limestone, Cotton, Glass-Sand, Bauxite, Clay, Lignite, Marble, Salt and Uranium (Nigeria Finder, 2018; Yahaya, 2017).

On the other hand, Venezuela is also endowed with other mineral resources aside petroleum such as Diamonds, Bauxite, Gold, Iron Ore, Natural Gas, and Aluminium. Venezuela can harness and invest in these resources for more revenues (AzoMining, 2018). Norway already has diverse geologic terrain which contains a broad spectrum of mineral resources for possible exploration, development and more revenues, including industrial minerals, metals and mineral fuels. Other mineral resources available in Norway apart from petroleum are natural gas, stone, iron ore, coal, nickel, titanium, sand and gravel (Newman, 2015). The Norwegian government have continued to expand other sectors of the economy even though the petroleum sector has been contributing to the major part of its revenues. However, in anticipation to an eventual decline in oil price, the Norwegian government has been saving a significant part of its oil revenues with the Sovereign Wealth Fund (SWF) which was valued at more than $\$ 700$ billion (Newman, 2015). How the Norwegian economy handled the "curse of oil" is worth emulating and would serve as a great lesson and reference to best practice to all the oildependent economies. Particularly, to Nigeria and Venezuelan economies in this period of the significant plunge in the oil revenues which has resulted in the nation's inability to finance their fiscal needs (Koranyi, 2014).

Nigeria and Venezuela could invest and diversify other sectors of the economy, thereby encouraging the production of more locally manufactured goods, hence, creating more employment and reducing the unemployment rate. There would then be an increase of oil and non-oil exports thereby increasing the government revenues of the nations and hence, improve the balance of payment account and increase the external reserves which would, in turn, lead to the improvement in economic growth and development of the nations. However, adequate monitoring, transparency and sound management system would have to be put in place in order to attain the desired goal. However, the underlying assumptions upon which the above model is based are as outlined:

i. The economies are assumed to be highly dependent on one primary source of revenue, say oil.

ii. It is also assumed that the price of oil is on the decrease, thereby leading to decline in oil revenue.

iii. We assume that the nations are also endowed with other natural resources other than oil, from which to harness.

iv. We also assume that the economies are willing to change or to move from mono-economy nations to more diversified nations in order to broaden the revenue base.

v. It is also assumed that the nations are highly vulnerable to oil price fluctuations, especially to negative oil price shocks which depletes the external reserves of the oil-exporters. 


\subsection{Summary of Findings and Conclusions}

The survey data analyses reveal that both increasing and decreasing oil price affects oil revenues of Nigeria, Venezuela and Norway proportionately. The results also reveal that the three economies need to explore other sources of revenue as a supportive effort in meeting with the budgetary needs of the economies. The results further show that the Norwegian government makes adequate effort in exploring alternative sources of generating revenues during periods of declining oil price which enables the economy in meeting with its budgetary needs while Nigeria and Venezuela's governments are not making adequate efforts in this exploration of alternative sources of revenue generation. Although the nations may have been engaged in some ways to expand the revenue source, but this study reveals that such efforts are not adequately carried out and not enough. The results also reveal that during periods of declining oil revenues, Nigeria attains its budgetary needs through borrowing, Venezuela attains its nations budgetary needs through borrowing and Seigniorage while Norway utilises its savings with the Sovereign Wealth Fund (SWF) and Pension Funds in meeting with its budgetary needs during periods of declining oil revenue. It also shows that both the Nigerian and Venezuela's government need to diversify the economy by investing on other sectors of the economy other than oil, practice good governance and manage the nation's resources effectively and efficiently while the Norwegian government continue with its diversification process and also continue to maintain the successful Norwegian model practice. From the results and findings, the following conclusions were deduced:

(i) The Nigeria, Venezuela and Norway are highly dependent on oil revenue as revealed from the results which indicate that oil revenue increases with the increase in oil price and reduces drastically as oil price declines.

(ii) Nigeria and Venezuela finance their budgetary needs through internal and external borrowing, in addition to that, Venezuela finances its fiscal needs through seigniorage, while the Norwegian government's expenditures are not affected by the declining oil revenue, since the economy has enough reserves in its Sovereign Wealth Funds (SWF) and Pension Funds during periods of windfall gains from oil and does not spend more than 4 per cent of its revenues on a yearly basis.

(iii) The external reserves of Nigeria, Venezuela and Norway, are highly affected by oil price fluctuations as it increases with the increasing oil price and declines as oil price falls. Thus, oil price and external reserves for each of these economies are directly proportional.

(iv) We can also conclude that there is an absolute need for Nigeria, Venezuela and Norway to adequately explore other sources of revenue which would serve as a supportive effort in meeting the budgetary needs of the nations.

(v) The Norwegian government is utilising the nation's natural resources effectively, unlike Nigerian and Venezuela.

(vi) Nigeria and Venezuela need to diversify the economies, practice the act of good governance and efficient management of the resources while the Norwegian economy continues to diversify its economy and continue to maintain the successful Norwegian economic model which has been working effectively for the nation over the years. Hence, Norway should serve as a reference to best practice to Nigeria, Venezuela and other similar countries that are ravaged by the resource curse syndrome. 


\section{Appendices}

Appendix A. Questionnaire for Nigeria

Please indicate the extent to which you agree or disagree with each of the statement on a five-point scale ranging from 5 to 1 , that is, strongly agree (5) Strongly Disagree (1). Please select one answer.

\begin{tabular}{|c|c|c|c|c|c|c|}
\hline S/No & Question/Statement & $\begin{array}{l}\text { Strongly } \\
\text { Agree } \\
\text { (5) }\end{array}$ & $\begin{array}{l}\text { Agree } \\
\text { (4) }\end{array}$ & $\begin{array}{c}\text { Neutral } \\
\text { (3) }\end{array}$ & $\begin{array}{c}\text { Disagree } \\
\text { (2) }\end{array}$ & $\begin{array}{l}\text { Strongly } \\
\text { Disagree } \\
\text { (1) }\end{array}$ \\
\hline & & & & & & \\
\hline & \begin{tabular}{|c|} 
CLOSED-ENDED OUESTIONS \\
\end{tabular} & & & & & \\
\hline Ql. & $\begin{array}{l}\text { Increasing oil revenue increases the revenue } \\
\text { base of the Nigerian economy. }\end{array}$ & & & & & \\
\hline Q2. & $\begin{array}{l}\text { Declining oil revenue adversely affects the } \\
\text { economic performance of the nation. }\end{array}$ & & & & & \\
\hline Q3. & $\begin{array}{l}\text { There is a need for other sources of revenue } \\
\text { to be explored as a supportive effort in } \\
\text { meeting the budgetary needs of the nation. }\end{array}$ & & & & & \\
\hline Q4. & $\begin{array}{l}\text { The Nigerian government makes adequate } \\
\text { efforts to explore alternative means of } \\
\text { generating revenue in times of declining oil } \\
\text { revenues to meet its budgetary needs. }\end{array}$ & & & & & \\
\hline Q5. & $\begin{array}{l}\text { The Nigerian government utilises the } \\
\text { nation's natural resources efficiently. }\end{array}$ & & & & & \\
\hline Q6. & $\begin{array}{l}\text { The government handles the nation's } \\
\text { budgetary problems effectively. }\end{array}$ & & & & & \\
\hline Q7. & $\begin{array}{l}\text { When decisions to increase or reduce the } \\
\text { budget of the economy are made, the } \\
\text { Nigerian government explains to the } \\
\text { populace the reasons for such decision. }\end{array}$ & & & & & \\
\hline Q8. & $\begin{array}{l}\text { The management of Nigeria's government } \\
\text { budget is very effective. }\end{array}$ & & & & & \\
\hline & & & & & & \\
\hline & OPEN-ENDED QUESTIONS & & & & & \\
\hline Q9. & $\begin{array}{l}\text { How does Nigeria attain its budgetary needs } \\
\text { during the periods of declining oil revenues? }\end{array}$ & & & & & \\
\hline Q10. & $\begin{array}{l}\text { What does the Nigerian government need to } \\
\text { do to improve its revenue base and } \\
\text { budgetary performance in times of declining } \\
\text { oil revenue? }\end{array}$ & & & & & \\
\hline
\end{tabular}

Source: Authors' design 
Appendix B. Questionnaire for Venezuela

Please indicate the extent to which you agree or disagree with each of the statement on a five-point scale ranging

from 5 to 1 , that is, strongly agree (5) Strongly Disagree (1). Please select one answer.

\begin{tabular}{|c|c|c|c|c|c|c|}
\hline S/No & Question/Statement & $\begin{array}{l}\text { Strongly } \\
\text { Agree } \\
\text { (5) }\end{array}$ & $\begin{array}{l}\text { Agree } \\
\text { (4) }\end{array}$ & $\begin{array}{c}\text { Neutral } \\
\text { (3) }\end{array}$ & $\begin{array}{c}\text { Disagree } \\
\text { (2) }\end{array}$ & $\begin{array}{l}\text { Strongly } \\
\text { Disagree } \\
\text { (1) }\end{array}$ \\
\hline & SI OSED FNDFD OITSTIONS & & & & & \\
\hline Ql. & $\begin{array}{l}\text { Increasing oil revenue increases the revenue } \\
\text { base of the Venezuelan economy. }\end{array}$ & & & & & \\
\hline Q2. & $\begin{array}{l}\text { Declining oil revenue adversely affects the } \\
\text { economic performance of the nation. }\end{array}$ & & & & & \\
\hline Q3. & $\begin{array}{l}\text { There is a need for other sources of revenue } \\
\text { to be explored as a supportive effort in } \\
\text { meeting the budgetary needs of the nation. }\end{array}$ & & & & & \\
\hline Q4. & $\begin{array}{l}\text { The Venezuelan government makes } \\
\text { adequate efforts to explore alternative } \\
\text { means of generating revenue in times of } \\
\text { declining oil revenues to meet its budgetary } \\
\text { needs. }\end{array}$ & & & & & \\
\hline Q5. & $\begin{array}{l}\text { The Venezuelan government utilises the } \\
\text { nation's natural resources efficiently. }\end{array}$ & & & & & \\
\hline Q6. & $\begin{array}{l}\text { The government handles the nation's } \\
\text { budgetary problems effectively. }\end{array}$ & & & & & \\
\hline Q7. & $\begin{array}{l}\text { When decisions to increase or reduce the } \\
\text { budget of the economy are made, the } \\
\text { Venezuelan government explains to the } \\
\text { populace the reasons for such decision. }\end{array}$ & & & & & \\
\hline Q8. & $\begin{array}{l}\text { The management of Venezuela's } \\
\text { government budget is very effective. }\end{array}$ & & & & & \\
\hline & & & & & & \\
\hline & OPEN-ENDED QUESTIONS & & & & & \\
\hline Q9. & $\begin{array}{l}\text { How does Venezuela attain its budgetary } \\
\text { needs during the periods of declining oil } \\
\text { revenues? }\end{array}$ & & & & & \\
\hline Q10. & $\begin{array}{l}\text { What does the Venezuelan government need } \\
\text { to do to improve its revenue base and } \\
\text { budgetary performance in times of declining } \\
\text { oil revenue? }\end{array}$ & & & & & \\
\hline
\end{tabular}

Source: Authors' design 
Appendix C. Questionnaire for Norway

Please indicate the extent to which you agree or disagree with each of the statement on a five-point scale ranging

from 5 to 1 , that is, strongly agree (5) Strongly Disagree (1). Please select one answer.

\begin{tabular}{|c|c|c|c|c|c|c|}
\hline S/No & Question/Statement & $\begin{array}{c}\text { Strongly } \\
\text { Agree } \\
(5)\end{array}$ & $\begin{array}{l}\text { Agree } \\
\text { (4) }\end{array}$ & $\begin{array}{c}\text { Neutral } \\
\text { (3) }\end{array}$ & $\begin{array}{c}\text { Disagree } \\
\text { (2) }\end{array}$ & $\begin{array}{l}\text { Strongly } \\
\text { Disagree } \\
\text { (1) }\end{array}$ \\
\hline & CLOSED-ENDED OUESTIONS & & & & & \\
\hline Q1. & $\begin{array}{l}\text { Increasing oil revenue increases the revenue } \\
\text { base of the Norwegian economy. }\end{array}$ & & & & & \\
\hline Q2. & $\begin{array}{l}\text { Declining oil revenue adversely affects the } \\
\text { economic performance of the nation. }\end{array}$ & & & & & \\
\hline Q3. & $\begin{array}{l}\text { There is a need for other sources of revenue } \\
\text { to be explored as a supportive effort in } \\
\text { meeting the budgetary needs of the nation. }\end{array}$ & & & & & \\
\hline Q4. & $\begin{array}{l}\text { The Norwegian government makes } \\
\text { adequate efforts to explore alternative } \\
\text { means of generating revenue in times of } \\
\text { declining oil revenues to meet its budgetary } \\
\text { needs. }\end{array}$ & & & & & \\
\hline Q5. & $\begin{array}{l}\text { The Norwegian government utilises the } \\
\text { nation's natural resources efficiently. }\end{array}$ & & & & & \\
\hline Q6. & $\begin{array}{l}\text { The government handles the nation's } \\
\text { budgetary problems effectively. }\end{array}$ & & & & & \\
\hline Q7. & $\begin{array}{l}\text { When decisions to increase or reduce the } \\
\text { budget of the economy are made, the } \\
\text { Norwegian government explains to the } \\
\text { populace the reasons for such decision. }\end{array}$ & & & & & \\
\hline Q8. & $\begin{array}{l}\text { The management of Norway's government } \\
\text { budget is very effective. }\end{array}$ & & & & & \\
\hline & & & & & & \\
\hline & OPEN-ENDED QUESTIONS & & & & & \\
\hline Q9. & $\begin{array}{l}\text { How does Norway attain its budgetary needs } \\
\text { during the periods of declining oil revenues? }\end{array}$ & & & & & \\
\hline Q10. & $\begin{array}{l}\text { What does the Norwegian government need } \\
\text { to do to improve its revenue base and } \\
\text { budgetary performance in times of declining } \\
\text { oil revenue? }\end{array}$ & & & & & \\
\hline
\end{tabular}

Source: Authors' design

\section{References}

Abubakar, M.Y., Sanusi, S.A. and Sabiu, B.S. (2016) 'Analysis of the impact of oil revenue on the Nigerian economy.' Journal of Economics and Finance (IOSR), 7(4), pp. 10-21.

Adamu, A. 2015. The Impact of Global Fall in Oil Prices on the Nigerian Crude Oil Revenue and Its Prices. Available

from: http://globalbizresearch.org/Dubai_Conference2015_May_2/conference/psd/D508.pdf(Accessed 4th February 2021).

Ademola, et al., (2015). Government Expenditure, Oil Revenue and Economic Growth in Nigeria. International Journal of Economics, Commerce and Management United Kingdom. III (5): pp.180-202.

Akinlo, A.E. (2012) 'How important is oil in Nigeria's economic growth?' Journal of Sustainable Development, 5(4), pp. p165. 
Akpan, U. F. and Atan, A. J. (2015) 'Macroeconomic Effects of Fiscal Policy Shock in Nigeria: A SVAR Approach.', International Journal of Economics and Business Research, Vol. 4(43), pp.109-120. DOI: $10.11648 /$ j.ijber.20150403.14

Ali, M.A., Saifullah, M.K. and Kari, F.B. (2015) 'The Impact of key Macroeconomic factors on Economic Growth of Bangladesh: A VAR Coo-integration Analysis.', International Journal of Management Excellence, 6(1), pp. 668-673.

Aliyan, A.M. (2013) 'Effect of oil prices fluctuations on industrial productions in Iran.' European Online Journal of Natural and Social Sciences, 2(4), pp. 572-583.

Allen, R. et al., (2015) IMF: The Evolving Functions and Organization of Finance Ministries. Available at: https://www.imf.org/external/pubs/ft/wp/2015/wp15232.pdf (Accessed: 13th December 2020).

Al-Qudsi, S. and Ali, M. (2016) Economic Growth Implications of Oil Price Fluctuations: The GCC Context. Available at: https://www.dohainstitute.edu.qa/MEEA2016/Downloads/Sulayman\%20AlQudsi.pdf (Accessed: 17th March 2021).

Amadeo, K. (2018) Congressional Budget Office, what it does and its impact. Available at: https://www.thebalance.com/congressional-budget-office-what-it-does-and-its-impact3305977?utm_term=budget + office\&utm_content=p1-main-1title\&utm medium $=$ sem\&utm source $=$ msn s\&utm campaign $=$ adid-71c9753e-e8ee-4db8-86073546684951c6-2-ab_msb_ocode-

$31744 \& \mathrm{ad}=$ semD\&an=msn_s\&am=broad\&q=budget + office\&o=31744\&qsrc=999\&l=sem\&askid $=71 \mathrm{c} 9753$ e-e8ee-4db8-8607-3546684951c6-2-ab_msb(Accessed: 7th June, 2020).

Andrews, M. (2013) 'The Limits of Institutional Reform in Development: Changing Rules for Realistic Solutions.' Cambridge: Cambridge University Press, 33(5), pp. 408-410.

Arewa, A. and Nwakahma, C. (2013) 'Macroeconomic variables and the dynamic effect of public expenditure: Long-term trend analysis in Nigeria.' Journal of Knowledge Management, Economics and Information Technology, 3(6), pp. 1-32.

Aydin, L. and Acar, M. (2011) 'Economic impact of oil price shocks on the Turkish economy in the coming decades: A dynamic CGE Analysis, Energy Policy, 39(3), pp. 1722-1731. doi: 10.1016/j.enpol.2010.12.051.

AZoMining (2018) Venezuela: Mining, Minerals and Fuel Resources. Available at: https://mail.google.com/mail/u/0/\#search/azomining?projector=1(Accessed: 05th February 2021).

Baruch, Y. and Holtom, B. C. (2008). Survey Response Rate Levels and Trends in Organizational Research. DOI: 10.1177/0018726708094863. SAGE Publications Los Angeles. 61(8): pp.1139-1160.

Basu, D. 2009. Economic Models Methods, Theory and Applications. doi $=10.1142 / 7085$. 1st ed. Singapore: World Scientific Publishing Co. Plc. Ltd.

Bentley, Y. and Bentley, R. (2015) 'Explaining the price of oil 1971-2014: The need to use reliable data on oil discovery and to account for 'mid-point' peak', Energy Policy, 86, pp. 880-890. doi: 10.1016/j.enpol.2015.04.028.

Blommestein, H. (2005) Role of the Ministry of Finance (MOF) in developing government bond markets suggested issues for discussion. Available at: http://www.oecd.org/finance/publicdebt/35325570.pdf (Accessed: 2nd December 2020).

Bohi, D. R. (1991). On the macroeconomic effects of energy price shocks. Resources and Energy. 13(2): pp.145162.

Bryman, A. (2008). Social Research Methods. $3^{\text {rd }}$ ed. New York: Oxford University press.

Bryman, A. (2016) Social Research Methods. 5th Edition ed. Italy: Oxford University Press.

Buvarp, P. (2015) Norway is not panicking about the oil price collapse. Available at: http://theconversation.com/why-norway-is-not-panicking-about-the-oil-price-collapse-37392 (Accessed: 16th November 2020).

Chukwuma, O.M. (2018) 'Diversification of Nigeria's Economy through Agriculture and Solid Minerals in the Face of Dwindling Economy.', International Journal of Advance Research and Innovation, 6(3), pp. 147151.

CIA World fact book (2016) Geographical names: Norway economy 2016. Available at: https://www.google.co.uk/search?q=World+FACTBOOK\%3A+Norway+Eeconomy+2016\&gws_rd=ssl (Accessed: 6th March 2019).

Cunado, J. and De Gracia, F.P. (2005) 'Oil prices, economic activity and inflation: evidence for some Asian countries', The Quarterly Review of Economics and Finance, 45(1), pp. 65-83.

Darby, M.R. (1982) 'The price of oil and world inflation and recessions.', American Economic Review, 72, pp. 738-751.

De Vos, A. S. (1998). Research at grassroots. A primer for the caring professions. 1998th ed. Pretoria, South Africa: Van Schaik Publishers.

Deutsche Bank Research (2014). 'Emerging Markets EM Oil Producers: Breakeven Pain thresholds'. Available 
from:

https:/etf.dws.com/DEU/DEU/Download/Research-Global/2dd759fe-b80a-4f07-a51cdd02f4d384e5/EM-oil-producers-breakeven-pain.pdf (Accessed: 27 May 2021).

Diego, R. (2018a) The Monetary and Fiscal History of Venezuela 1960-2016. Available at: https://www.economics.utoronto.ca/diegor/research/MFHLA_paper.pdf (Accessed: 5th March 2019).

Diego, R. (2018b) The Monetary and Fiscal History of Venezuela 1960-2016. Available at: https://www.economics.utoronto.ca/diegor/research/MFHLA_paper.pdf (Accessed: 15th July 2019).

Dizaji, S.F. (2014) 'The effects of oil shocks on government expenditures and government revenues nexus (with an application to Iran's sanctions)', Economic Modelling, 40, pp. 299-313.

Ekeocha, P.C. (2012) 'An analysis of the federal budgeting process in Nigeria: Implications for institutional reforms for achieving timeliness.', Developing Country Studies, 2(6), pp. 64-77.

Ekperiware, M. C. and Olomu, M. O. (2015) 'Effect of Oil and Agriculture on Economic Growth in Nigeria', Journal of Global Economics, Management and Business Research, 3(2), pp. 75-86.

Ellis, R.E. (2017) The Collapse of Venezuela and Its Impact on the Region; Available at: http://www.addisonlibrary.org/sites/default/files/The\%20Collapse\%20of\%20Venezuela.pdf (Accessed: 18th November 2020).

Eltejaei, E. (2015) 'Oil, government's budget and economic growth in Iran.', International Journal of Economic Policy in Emerging Economies, 8(3), pp. 213-228.

Eltony, N. and Al-Awadi, M. (2001) 'Oil price fluctuations and their impact on the macroeconomic variables of Kuwait: A case study using a VAR model.', International Journal of Energy Research, 25(11), pp. 939-95 doi: https://doi.org/10.1002/er.731.

Eze, M. A. and Kouhy, R. (2021) 'Episodes of Fluctuating Oil Prices Through the New-Normal Era: The Historical Perspective (1946-2020).', Historical Research Letter, Vol. 53(2021), pp.16-39. DOI: 10.7176/HRL/53-0

Faber J. and Fonseca, L. M. (2014). 'How Sample Size Influences Research Outcomes', Dental Press Journal of Orthodontics, Vol. 19(4), pp.27-29. DOI: 10.1590/2176-9451.19.4.027-029.ebo

Fahey, M. (2015) Oil Prices and Budgets: The OPEC Countries Most at Risk. Available at: http://www.cnbc.com/2015/12/03/oil-prices-and-budgetsthe-opec-countries-most-at-risk.html (Accessed: 20 January 2021).

Farzanegan, M. R. (2011) 'Oil revenue shocks and government spending behaviour in Iran', Energy Economics, 33(6), pp. 1055. doi: 10.1016/j.eneco.2011.05.005.

Farzanegan, M.R. and Markwardt, G. (2009) 'The effects of oil price shocks on the Iranian economy', Energy Economics, 31(1), pp. 134-151. doi: 10.1016/j.eneco.2008.09.003.

Frankfort-Nachmias, C. and Nachmias, D. (2008). Research methods in the social sciences. 7th ed. New York: Worth Publishers, Inc.

Halid, O.Y. (2015) 'The Cobb-Douglas Production of the Nigerian Economy (1974-2009)', International Journal of Statistics and Applications, 5(2), pp. 77-80.

Hamilton, J. D. and Herrera, A. M. (2004). "Oil Shocks and Aggregate Macroeconomic Behaviour: The Role of the Monetary Policy,". Journal of Money, Credit and Banking. 36(2): pp.265-286.

Hamilton, J.D. (1983) 'Oil and the Macroeconomy since World War II', Journal of Political Economy, 91(2), pp. 228-248. doi: 10.1086/261140.

Hamilton, J.D. (2003) 'What is an Oil Shock?', Journal of econometrics, 113(2), pp. 363-398.

Hamilton, J.D. (2005) 'Oil and the Macroeconomy', The New Palgrave Dictionary of Economics Palgrave Macmillan, London. Available online at http://www.dictionaryofeconomics.com/dictionary.JiménezRodríguez, Rebeca and Marcelo Sánchez, pp. 201-228.

Hamilton, J.D. (2009a) "'Understanding Crude Oil Prices". The Energy Journal, International Association for Energy Economics.', The Energy Journal, 30(2), pp. 179-206. doi: 10.5547/ISSN0195-6574-EJ-Vol30No2-9.

Hamilton, J.D. (2009b) Causes and Consequences of the Oil Shock of 2007-08. Available at: http://www.brookings.edu/about/projects/bpea/editions/ /media/Projects/BPEA/Spring\%202009/2009a bpea_hamilton.PDF (Accessed: 15 January 2021).

Hamilton, $\quad$ J.D. (2011) Historical Oil Shocks. Available at: http://econweb.ucsd.edu/ jhamilton/oil_history.pdf (Accessed: 9th January 2021).

Hass et al. (2017) Oil and Gas Statistics: The Norwegian Experience. Available at: https://www.ssb.no/energiog-industri/artikler-og-publikasjoner/_attachment/311820?_ts=15c88155370 (Accessed: 23rd February 2021).

Hassan, A. (2013) 'Review of the global oil and gas industry: A concise journey from ancient time to modern world.', Petroleum Technology Development Journal, 3(2), pp. 123-141.

Hayes, A. (2015) Falling oil prices could bankrupt these countries. Available at: http://www.investopedia.com/articles/active-trading/020215/falling-oil-prices-could-bankrupt-these- 
countries.asp (Accessed: 23 March 2021).

Hesary, F.T., Yoshino, N., Abdoli, G. and Farzinvash, A. (2013) 'An Estimation of the Impact of Oil Shocks on Crude Oil Exporting Economies and Their Trade Partners', Frontiers of Economics in China, 8(4), pp. 571591. doi: 10.3868/s060-002-013-0029-3.

Holden, S. (2011). Avoiding the Resource Curse: The Case Norway. Available from: http://folk.uio.no/sholden/wp/oil-ghana-norway.pdf (Accessed 4th April 2021).

Hooker, M. A. (1996). What happened to the oil price macro-economy relationship? Journal of Monetary Economics. 38(2): pp.195-213.

Hooker, M.A. (1999) Are oil shocks inflationary? Asymmetric and nonlinear specifications versus changes in regime. Available at: https://www.federalreserve.gov/pubs/feds/1999/199965/199965pap.pdf (Accessed: 14 July 2020).

Husain, A.M. et al., (2015) Global implications of lower oil prices: International Monetary Fund. Available at: https://www.imf.org/external/pubs/ft/sdn/2015/sdn1515.pdf (Accessed: 15th March 2020).

Hutchinson, E. (2016) Principles of Microeconomics. 1st Ed. University of Victoria, Canada: OpenStax.

Igbara, et al., (2016) 'Budget and budgeting in the third tier of Government: Problems and prospects.', Equatorial Journal of Finance and Management Sciences, 1(1), pp. 1-9.

International Budget Partnership (2011) Guide to the open budget questionnaire: An explanation of the questions and the response options. Available at: https://www.internationalbudget.org/wp-content/uploads/GuideOBS2012_English-Final.pdf (Accessed: 17th January 2021).

Iwayemi A. and Fowowe, B. 2011. Impact of Oil Price Shocks on Selected Macroeconomic variables in Nigeria. Energy Policy. 39(2): pp.603-612.

Joshua, S.R., Gubak, H.D. and Dankumo, A.M. (2016) 'Growth of Non-Oil Sectors: A Key to Diversification and Economic Performance in Nigeria.', Public Policy and Administration Research, 6(3), pp. Online.

Kabir, M. (2014) 'Vector Auto regressive model and the Nigerian Economy', Journal of Economics and Sustainable Development, 5(14), pp. 129-137.

Kaplan, F. (2015). Oil Price, Exchange Rate and Economic Growth in Russia: A Multiple Structural Break Approach. Advances in Management and Applied Economics. 5(4): pp.91.

Kilian, L. (2009). Oil Price Volatility: Origins and Effects. doi:10.30875/9b9f6bc8-en. Available from: https://www.econstor.eu/bitstream/10419/57602/1/639727123.pdf [Accessed 26th July 2020].

Kilian, L. and Lutkepohl, H. (2016) Structural Vector Autoregressive Analysis. Available at: http://wwwpersonal.umich.edu/ lkilian/SVARbook_frontmatter.pdf (Accessed: 12th September 2020).

Kitous, A., Saveyn, B., Keramas, K., Vandyck, T., Santos, L. and Wojtowicz, K. (2016) Impact of Low Oil Prices on Oil Exporting Countries. Available at: http://publications.jrc.ec.europa.eu/repository/bitstream/JRC101562/jrc101562_impact\%20of\%20low\%2 0oil\%20prices\%2020160512.pdf (Accessed: 20 July 2020).

Koranyi, B. (2014) End of oil boom threatens Norway's welfare model. Available at: https://www.reuters.com/article/us-norway-economy-insight/end-of-oil-boom-threatens-norwayswelfare-model-idUSBREA4703Z20140508 (Accessed: 9th September 2020).

Krakenes, A.T. (2015) Norway: Revenue from oil fund now exceeds revenue from oil. Available at: https://eiti.org/news/norway-revenue-from-oil-fund-now-exceeds-revenue-from-oil (Accessed: 23rd February 2021).

Lee, K., Ni, S. and Ratti, R. A. (1995). "Oil Shocks and the Macroeconomy: The Role of Price Variability,”. The Energy Journal. 16(4): pp.39-56. doi.org/10.5547/ISSN0195-6574-EJ-Vol16-No4-2

Likert, R. (1932). A Technique for the Measurement of Attitudes. Available from: https://legacy.voteview.com/pdf/Likert_1932.pdf [Accessed 7th March 2018].

Lorusso, M. and Pieroni, L. (2015) Causes and Consequences of Oil Price Shocks on the UK Economy. Centre for Energy Economics Research and Policy (CEERP). Available at: http://ceerp.hw.ac.uk/RePEc/hwc/wpaper/002.pdf (Accessed: 15 July 2020).

Luković, S. and Grbić, M. (2014). The Causal Relationship Between Government Revenue and Expenditure in Serbia. Economic Themes. 52(2): pp.127-138 DOI 10.1515/ethemes-2014-0009.

Magoti, E. and Mtui, J. M. (2020). 'The Relationship between Economic Growth and Service Sector in Tanzania: Empirical Investigation', African Journal of Economic Review, Vol. III, Issue II, pp.219-238.

Malhotra, N. K. and Birks, D. F. (2000). Marketing Research, European edition: An applied approach. 2 nd ed. Financial Times/ Prentice Hall.

Mellor, D.J. and Moore, K. A. 2014. The use of Likert scales with children. Journal of Pediatric Psychology. 39(3): pp.369-379 DOI:10.1093/jpepsy/jst079.

Mohaddes, K. and Raissi, M. (2015) IMF working paper: the US oil supply revolution and the global economy. Available at: http://www.imf.org/external/pubs/ft/wp/2015/wp15259.pdf (Accessed: 17 March 2021). 
Monaldi, F. (2015). The Impact of the Decline in Oil Prices on the Economics, Politics and Oil Industry of Venezuela. Available from: https://energypolicy.columbia.edu/sites/default/files/Impact $\% 20$ of $\% 20$ the $\% 20$ Decline $\% 20 \mathrm{in} \% 20 \mathrm{Oil}$ \%20Prices\%20on\%20Venezuela_September\%202015.pdf (Accessed 9th June 2021).

Montgomery, R., Dennis, J. M. and Ganesh, N. (2016) Response Rate Calculation Methodology for Recruitment of a Two-Phase Probability-Based Panel: The Case of AmeriSpeak. Available at: https://d3qi0qp55mx5f5.cloudfront.net/amerispeak/i/research/WhitePaper_ResponseRateCalculation_A meriSpeak 2016.pdf (Accessed: 20 November 2018).

Mork, K.A. (1989) 'Oil and the Macroeconomy When Prices Go Up and Down: An Extension of Hamilton's Results', Journal of Political Economy, 97(3), pp. 740-744. doi: 10.1086/261625.

Moses, J. W. and Letnes, B. (2017) 'Breaking Brent: Norway's response to the recent oil price shock', The Journal of World Energy Law \& Business, 10(2), pp. 103-116. doi: //doi.org/10.1093/jwelb/jwx004.

Nelson, R.M. (2018a): Venezuela's Economic Crisis: Issues for Congress. Specialist in International Trade Finance. Available at: https://fas.org/sgp/crs/row/R45072.pdf (Accessed: 4th February, 2021).

Newman, H.R. (2015) 2012 Minerals Yearbook: The Mineral Industry of Norway. Available at: https://minerals.usgs.gov/minerals/pubs/country/2012/myb3-2012-no.pdf (Accessed: 11th February 2021).

Nicholson, W. and Snyder, C. (2007) Microeconomic Theory: Basic Principles and Extensions. $10^{\text {th }}$ Ed. Thomson Higher Education. United States of America

Nigerian Finder (2018) Natural Resources in Nigeria: The Full List and Locations. Available at: https://nigerianfinder.com/natural-resources-in-nigeria-the-full-list-locations/ (Accessed: 08th February 2021).

Nkoro, E. and Uko, A.K. (2016) 'Autoregressive Distributed Lag (ARDL) Cointegration Technique: Application and Interpretation', Journal of Statistical and Econometric Methods, 5(4), pp. 63-91.

Norway Ministry of Finance, (2021): The Government Pension Fund, the National Budget, Direct and Indirect Taxes and Economic Policy. Available at: https://www.regjeringen.no/en/dep/fin/id216/ (Accessed: 20 January 2021)

Norway: The National Budget (2018): A Summary. Available at: https://www.regjeringen.no/globalassets/upload/fin/statsbudsjettet/english/2018_national_budget.pdf. (Accessed: 15 May 2021)

Nwankpa, L. O. and Okeke, R. C. (2017) 'Budgeting for Change in the Nigerian Public sector: A Qualitative Research', An International Multi-Disciplinary Journal, Bahir Dar, Ethiopia, 11(4), pp. 7-16. doi: //dx.doi.org/10.4314/afrrev.v11i4.2.

Nwaobi, G.C. (2005) 'Oil Policy in Nigeria: A Critical Assessment (1958-1992). Available $a t:$ https://www.researchgate.net/profile/Godwin_Nwaobi/publication/23749230_Oil_Policy_In_Nigeria_A_ Critical Assessment19581992/links/5448a1d80cf2f14fb8142a97/Oil-Policy-In-Nigeria-A-CriticalAssessment1958-1992.pdf. (Accessed: 16th May 2017).

Nwosu, D. C. and Okafor, H. O. (2014). Government Revenue and Expenditure in Nigeria: A Disaggregated Analysis. Asian Economic and Financial Review. 4(7): pp.877-892.

Nzimande, N.P. and Msomis, S. (2016) Oil Price Shocks and Economic Activity: The Asymmetric Cointegration Approach in South Africa. Available at: http://saef.ukzn.ac.za/Libraries/Working_Paper/SAEF_Oil_Price_Shocks-NN_SM.sflb.ashx (Accessed: 16 July 2020).

Ogundipe, O. M., Ojeaga, P. and Ogundipe, A. A. (2014) 'Oil Price and Exchange Rate Volatility in Nigeria', Journal of Economics and Finance (IOSR), 5(4), pp. 1-9

OilPrice.com (2021) The No. 1 Source for Oil and Energy News. Available at: https://oilprice.com/Energy/Crude-Oil/Why-The-Oil-Price-Bear-Market-Persists.html

Olaoye, F.O. (2014) 'An exploratory evaluation of legislative lawlessness in the Nigerian budget process.', Singaporean Journal of Business, Economics and Management Studies, 3(2), pp. 39-47.

Olomola, P.A. and Adejumo, A.V. (2006). Oil price shock and macroeconomic activities in Nigeria. International Research Journal of Finance and Economics. 3(1): pp.28-34.

Olsen, O. (2018) Øystein Olsen: Does Norway save too much? Available at: https://www.bis.org/review/r180327d.pdf (Accessed: 12th February 2021).

OPEC Annual Statistical Bulletin (2018) OPEC share of world crude oil reserves, 2017. Available at: https://www.opec.org/opec_web/en/data_graphs/330.htm (Accessed: 5th December 2020).

Oriakhi, D. E. and Iyoha, O. D. (2013). Oil Price Volatility and its Consequences on the Growth of the Nigerian Economy: An Examination (1970-2010). Asian Economic and Financial Review. 3(5): pp.683-702.

Osuji, E. (2015). 'International Oil Prices and Exchange Rate in Nigeria: A Causality Analysis'. International 
Journal of Academic Research in Economic and Management Sciences. 4(3), Pp 11-22.

Ouliaris, S., Pagan, A. R. and Restrepo, J. (2018). Quantitative Macroeconomic Modeling with Structural Vector Autoregressions - $\quad$ An EViews Implementation. Available from: https://www.eviews.com/StructVAR/structvar.html [Accessed 13th April 2021].

Oyelami, L. (2018) 'Effects of Oil Price Movement on Nigerian Macroeconomic Variables: Evidence from Linear and Nonlinear ARDL Modelling.', Iran Economic Review, 22(4), pp. 908-933.

Paiko, I. I. (2012). Deficit Financing and its Implication on Private Sector Investment: The Nigerian Experience. Arabian Journal of Business and Management Review. 1(9): pp.45-62 DOI: 10.12816/0002187.

Paraskova, T. (2020) Norway's 2021 Oil Investments Set to Fall Less than Feared. Available at: https:/oilprice.com/Latest-Energy-News/World-News/Norways-2021-Oil-Investments-Set-To-FallLess-Than-Feared.html (Accessed: 17th May 2021).

Peng, J.; Li, Z. and Drakeford, B. M. (2020) Dynamic Characteristics of Crude Oil Price Fluctuation - From the Perspective of Crude Oil Price Influence Mechanism.' Energies, Vol. 13(17), pp.1-19. DOI: https://doi.org/10.3390/en13174465

Pescaroli, G., Velazquez, O., Alcántara-Ayala, I. et al., (2020). A Likert Scale-Based Model for Benchmarking Operational Capacity, Organizational Resilience, and Disaster Risk Reduction. Int J Disaster Risk 404-409. https://doi.org/10.1007/s13753-020-00276-9

Pettinger, T. (2015) Impact of Falling Sci 11, Oil $\quad$ Prices. Available at: http://www.economicshelp.org/blog/11738/oil/impact-of-falling-oil-prices/ (Accessed: 17 ${ }^{\text {th }}$ June 2020).

Rascouet, A. (2015) Bloomberg: Oil States Need Price Jump to Balance Budget - OPEC Reality Check. Available at: http://www.bloomberg.com/news/articles/2015-11-30/oil-states-need-price-jump-tobalance-budget-opec-reality-check (Accessed: 26 July 2020).

Recknagel, C. (2016) What can Norway teach other oil-rich countries? Available at: http://www.rferl.org/content/what-can-norway-teach-other-oil-rich-countries/26713453.html (Accessed: 6 March 2021).

Revenue Watch Index Questionnaire (2009) Guide for Researchers. Available at: http://www.revenuewatch.org/rwindex2010/pdf/RW_Index_ResearchersGuide.pdf (Accessed: 9th December 2020).

Roespinoedji, D.; Roespinoedji, R.; Siam, M. R. A. and Shamsudin, M. F. (2019) 'An Empirical Study on Short Term and Long-term Consequences of Crude Oil on Economic Wellbeing of Indonesia by Applying Autoregressive Distributed Lag Model.', International Journal of Energy Economics and Policy, Vol. 9(5), pp.474-480. DOI: 10.32479/ijeep.8311

Sam-Tsokwa, A. T. and Ngara, C. O. (2016) 'The National Assembly and the budget process in Nigeria's Fourth Republic: Tackling the challenges of timeliness.', Canadian Social Science, 12(5), pp. 1-7.

Sanchez, C. A., and Goolsbee, J. Z. 2010. Character size and reading to remember from small displays. Computers and Education. 55(3): pp.1056-1062 https://doi.org/10.1177/154193121005401905,

Sauro, J. (2011) How to Estimate a Survey Response Rate. Available at: https://measuringu.com/responserate/ (Accessed: 15th November 2019).

Schipani, A. (2015) Facing up to cheap oil: A tale of Latin America's two Opec Members. Available at: http://blogs.ft.com/beyond-brics/author/andresschipani/ (Accessed: 12th September 2020).

Sharma, M. and Bilgic, M. (2017). Evidence-based uncertainty sampling for active learning. Data Mining and Knowledge Discovery. 31(1): pp.164-202.

Shi, X. and Sun, S. (2012) Oil Price Shock and Macroeconomy in China and India: Insights from the Energy Sector. Available at: file://C:/Users/1404750/Downloads/Shi2012abstract\%20(1).pdf (Accessed: $15^{\text {th }}$ March 2021).

Shyam, A. (2018) Producer's fiscal break-even a key factor in setting oil prices. Available at: https:/economictimes.indiatimes.com/markets/commodities/news/producers-fiscal-break-even-a-keyfactor-in-setting-oil-prices/articleshow/67225321.cms?from=mdr (Accessed: 20 December 2020).

Taghizadeh-Hesary, F. (2020) Economic impacts of the COVID-19 pandemic and oil price collapse. Available at: https://www.asiapathways-adbi.org/2020/05/economic-impacts-covid-19-pandemic-and-oil-pricecollapse/ (Accessed: 17th March 2021).

Taghizadeh-Hesary, F. and Yoshino, N. (2015) Macroeconomic Effects of Oil Price Fluctuations on Emerging and Developed Economies in a Model Incorporating Monetary Variables. Available at: https://www.econstor.eu/bitstream/10419/145394/1/838107419.pdf (Accessed: 7th January 2021).

The World Bank (2016) Global Economic Prospects. Available at: http://www.worldbank.org/en/publication/global-economic-prospects (Accessed: 6 June 2020).

Tong, S. (2016) How oil rich Venezuela ended up with a miserable economy. Available at: http://www.marketplace.org/2016/04/01/world/resource-curse/how-plummeting-global-oil-prices-havedevastated-venezuela (Accessed: 16th December 2020). 
Udo, B. (2014) Exclusive: Finance Ministry, Budget Office, among agencies with thousands of ghost workers. Premium Times. Available at: https://www.premiumtimesng.com/news/165806-exclusive-finance-ministrybudget-office-among-agencies-with-thousands-of-ghost-workers.html(Accessed: 7th June 2020).

Van Eyden, R.; Difeto, M.; Gupta, R.; Wohar, M.E. (2019). 'Oil price volatility and economic growth: Evidence from advanced economies using more than a century’s data.’, Applied Energy, Vol. 233-234, pp.612-621. https://doi.org/10.1016/j.apenergy.2018.10.049.

Weisbrot, M. and Sandoval, L. (2008) Centre for Economic and Policy Research (CEPR): The Venezuelan Economy in the Chávez Years. Available at: https://core.ac.uk/download/pdf/6967541.pdf (Accessed: 15th November 2020).

Workman, D. (2016) Crude Oil Exports by Country. Available at: http:/www.worldstopexports.com/worlds-topoil-exports-country/ (Accessed: 22nd January 2020).

Yahaya, A. (2017) Major Mineral Resources in Nigeria: Full List and Loctions. Available at: https://www.nigerianinfopedia.com/major-mineral-resources-in-nigeria-full-list-locations/ (Accessed: 08th February 2021).

Yanar, R. (2014)Effects of oil price plunge on the MENA economies. Available at: http://www.orsam.org.tr/files/Raporlar/rapor194/194eng.pdf(Accessed: 7th December 2020).

Yoshino, N. and Taghizadeh-Hesary, F. (2014) 'Economic impacts of oil price fluctuations in developed and emerging economies', IEEJ Energy Journal, 9(3), pp. 58-75. 